\title{
VITALITY ANALYSIS AS A CONSTITUENT \\ OF THE POPULATION STUDIES OF NATURAL REFORESTATION
}

\section{Skliar Viktoriia ${ }^{1}$ \\ Sherstiuk Maryna ${ }^{2}$}

DOI: https://doi.org/10.30525/978-9934-571-78-7_52

\begin{abstract}
The article focuses on the original approaches to the division of woody plant populations into individual structural groups - cohorts: seedlings, plantlets, small undergrowth, medium undergrowth, large undergrowth, young and generative trees of the tree layer. It is shown that the peculiarities of the natural reforestation process are indicative of the six generalizing models. One of them (Isp-Usml-Tym) corresponds to the renewal, which begins with the formation of seedlings of forest-forming species under the forest canopy that gradually reach the level of forest stand and generative ontogenetic state, gaining the ability to form the next cycle of natural reforestation. The other five (I-Usml-Ty, I-Usml, I-Usm, I-Us, I) characterize the situation where natural reforestation is not cyclical due to the fact that individuals of young generation cease to develop and exist before their transition to a generative ontogenetic state. The expediency of application of the vitality analysis to evaluate cohorts is justified. The authors' approaches to the study of the dynamics of vitality structure of cohorts by the stages of natural reforestation are proposed. The vitality structure of Pinus sylvestris L. cohorts formed in different forest site conditions of Left-Bank Polissia of Ukraine and its change by the stages of natural reforestation are described in detail. It is proved that in various models of natural reforestation the vitality cohort structure acts as a separate and very dynamic characteristic. The change in the characteristic features of the vitality structure by the stages of natural reforestation in P. sylvestris is very diverse. Despite the fact that the $P$. sylvestris cohorts of different groups of associations vary significantly by vitality parameters, there are clearly defined patterns in change in values of the quality index and vitality
\end{abstract}

\footnotetext{
${ }^{1}$ Doctor of Biology Sciences, Professor of the Department of Ecology and Botany, Sumy National Agrarian University, Ukraine

${ }^{2}$ Candidate of Biology Sciences, Assistant of the Department of the Landscaping and Forestry, Sumy National Agrarian University, Ukraine
} 
structure on simple gradients of the major ecological-coenotic factors. The vitality parameters of $P$. sylvestris cohorts are a response to the influence of a number of ecological and coenotic factors inherent in a particular habitat. The dynamics of vitality structure is manifested in the wide-scale implementation of its spatial and temporal variability and flexibility. On the territory of the Left-Bank Polissia of Ukraine, Pinus sylvestris is mainly dominated by the models of incomplete natural reforestation.

\section{Introduction}

In the vegetation cover of the Earth, forests play a leading role by the occupied area and significance. An important component of the functioning of forest communities is natural reforestation $[4 ; 5 ; 9 ; 11]$. It is a complex, long and multi-stage process, during which individuals of a new generation of forest-forming species undergo the qualitative and quantitative changes that ensure a consistent transition of these plants from one tree layer to the other and their achievement of the level of forest stand.

As of today, the interactions and transformations that are crucial both for undergoing each individual stage of reforestation and forming a continuous flow of generations of forest-forming species, and, finally, for ensuring the sustainable existence and operation of forest phytocoenoses, have not been fully clarified yet. Their study is an urgent scientific problem that is of great practical importance and requires the application of classical and modern biological methods. Among them, the ecological-coenotic approach and population studies are distinguished by a high level of information content. An important component of the latter is the vitality analysis.

The goal of the paper is to reveal the essence of the latest approaches to the assessment of natural reforestation, which are based on the application of vitality analysis, and to highlight the aspects of their implementation on the example of one of the key forest-forming species of Ukraine - Pinus sylvestris L.

\section{Basic general methodological aspects of the study of natural reforestation}

Following the results of our studies of the natural reforestation process conducted for more than ten years, we have developed a system of division of woody plant populations into structural intra-population groups cohorts. It is based on the undergrowth and tree recording technique adopted 
in forestry and supplemented by the assessment of the size of plants, their ontogenetic state and position in the architectonics of the forest ecosystem. The following cohorts are distinguished in the populations of the major forest-forming species:

1. Seedlings. These are the plants that appear in spring of the current year. A characteristic feature of individuals of the species with epigeal germination is the presence of cotyledons, and with hypogeal germination - cataphylls. As usual, these plants are found in the above-soil layer below the main canopy of leaf cover of the herbaceous and subshrub layer. In some of phytocoenoses, seedlings are at the level of a moss layer. In the generally accepted system of discrete description of ontogenesis they correspond to the category " $p$ ".

2. Plantlets. These are mostly 1 - to 3 -year-old plants. They have true leaves, predominantly of a juvenile type. Depending on a tree species, they are mostly found under a canopy of leaf cover of the herbaceous and subshrub layer or occupy its lower part. By the ontogenetic state this group is mixed and may include individuals of the category " $p$ " and juvenile individuals of the category " $\mathrm{j}$ ".

3. Small undergrowth. This is a cohort of plants, which is located entirely in the herbaceous and subshrub layer of forest phytocoenosis. Individuals are up to $50 \mathrm{~cm}$, rarely - up to $60-70 \mathrm{~cm}$ in height. Their root system is surface. The calendar age ranges from 3-5 years to decades. By the ontogenetic state these are juvenile or immature individuals, and in adverse environmental conditions, even the so-called quasi-senile ("stump plants").

4. Medium undergrowth. The plants of this cohort "emerge" from the herbaceous and subshrub layer and "are embedded" in the undergrowth layer. The individuals of the middle undergrowth are mainly from $0.5 \mathrm{~m}$ to $2.5 \mathrm{~m}$ in height. By the calendar age they are very different: $10-11$ and more years. These are predominantly immature, less commonly, virginile plants. All of them are characterized by a fairly rapid growth in height.

5. Large undergrowth. Individuals of a cohort of large undergrowth are in the undergrowth layer. Compared with small and medium undergrowth, their root system is located in the deeper soil layers. They are mostly plants with a height of 2.5 to $8.0 \mathrm{~m}$. Their calendar age is usually more than 20-25 years (depending on species).

6. Young trees of the upper layer of the forest are in a state of "being embedded" in a tree layer of the forest stand. These are the virginile individuals, which are a little lower than the main canopy of the forest stand. 


\section{Chapter «Biological sciences»}

7. Mature trees (generative trees) of the upper layer of the forest. This cohort consists of plants of $\mathrm{g} 1-\mathrm{g} 3$ states. It also includes the subsenile individuals, which still retain reproductive ability. The height and age of trees are determined by their species.

When making the general characterization, the cohorts 1-6 were considered as the young generation of one or another forest-forming species, and the cohorts 3-5 as its undergrowth. Each of the cohorts, as a structural intra-population group, is characterized by certain differences in the state of the individuals included in its composition. This is the basis for conducting the population-based studies and, in particular, the vitality analysis, in relation to them. It provides an assessment of the vitality of individuals by morphological characteristics, followed by the determination of the ratio of a number of individuals of different vitality in the population. The theoretical basis and vitality analysis algorithm have been formulated by Yu.A. Zlobin [1-3].

\section{Use of the vitality analysis to study natural reforestation}

The unconditional advantage of the vitality analysis is that it excludes a subjective approach and enables to obtain the unified data on the vitality of individuals and their populations by 1-3 morphological characteristics determined based on the methods of mathematical statistics. The definition of key morphological parameters, that is, the indicators that are the objective quantitative reflection of the vitality level, is the most important and demanding stage of the vitality analysis. As usual, it provides for implementing the following stages of the calculation procedure: 1. The selection of morphological parameters with the highest level of variation; 2. The application of factor analysis to these indicators; 3 . The assessment of the level of correlation relationships between all dimensional indicators and the formation of correlation pleiads; 4 . The comparison of the results of factor and correlation solutions; 5. The interpretation of the obtained data based on biological and ecological rules and regularities.

On the basis of theoretical generalizations, the vitality analysis of P. sylvestris trees as the major forest-forming species of Left-Bank Polissia of Ukraine, as well as large and medium undergrowth was made in our work based on such key morphological parameters as the height of individuals and the diameter of their trunk. This analysis was applied to trees taking into account the belonging of plants to a certain age class. 
Small undergrowth is one of the cohorts of the young generation of tree species, which is understudied in the morphological terms. In our studies, based on the results of applying the vitality analysis algorithm to P. sylvestris small undergrowth, the absolute growth rate of phytomass (AGRW), the absolute growth rate of height (AGRH) and the number of primary side shoots per plant height $(\mathrm{B} / \mathrm{h})$ were chosen as the key morphological parameters. The key morphological parameters for seedlings and plantlets were the height and phytomass of individuals.

The final stage of the vitality analysis calculations is aimed at determining, based on the key morphological parameters, the share of plants with different levels of vitality (vitality classes "a", "b" and "c") as part of the cohorts and establishing its type by the quality index value (Q). Due to availability of the computer program VITAL developed by Yu.A. Zlobin, the specified stage of the calculation procedure is fast and automated.

\section{Variety of natural reforestation models and the evaluation of vitality dynamics}

In general, change in vitality features and vital capacity of certain plant populations in a time domain is still understudied, and constitutes a separate scientific challenge. It is also relevant for tree species, especially in the aspect of ensuring their natural recovery.

In order to unify the studies on the dynamics of vitality parameters of forest-forming species cohorts available under the canopy of parent stands, we have distinguished the three main phases in the process of natural reforestation, taking into account the principles of domestic forestry, as well as achievements of scientists from other countries in this area [4; 7-10]:

1. Initial phase.

2. Phase of undergrowth formation, growth and development (Undergrowth phase).

3. Phase of transition of the young generation of forest-forming species to the tree stand (Tree stand phase).

The first one corresponds to the stage of appearance and enshrinement of cohorts of seedlings and plantlets in the forests. The second phase is characterized by the development of the cohorts of undergrowth: small, medium and large. The third phase is final in the natural reforestation cycle. It may provide for two substages: the formation of cohorts of young and mature trees. 
Depending on diversity of the above phases and stages, natural reforestation may be either complete or incomplete. We consider it possible to indicate the first of them as the Isp-Usml-Tym model or its shortened version I-U-T. This model corresponds to the natural reforestation that begins with the formation of seedlings of forest-forming species, which gradually reach the level of forest stand and generative state, in the forests.

Under the incomplete natural reforestation, "cyclicity" in the self-renewal of forest phytocoenoses is not achieved. The degree of incompleteness may vary. The specified feature of natural reforestation is illustrated by means of the special models given below.

- I-Usml-Ty - young generation of a forest-forming species from the initial phase undergoes all stages of recovery, reaches the level of forest stand, but ceases to develop and often exist, at the level of a cohort of young trees;

- I-Usml - natural reforestation terminates when the young generation of forest-forming species reaches the state of large undergrowth;

- I-Usm - natural reforestation terminates when the young generation of forest-forming species reaches the state of medium undergrowth;

- I-Us - natural reforestation terminates when the young generation of forest-forming species reaches the state of small undergrowth;

- I - natural reforestation terminates when the young generation of forest-forming species is at the initial phase (at the level of seedlings or plantlets) of this process.

Under natural reforestation, in the transition of plants from one stage to another the following options may be implemented: a) improvement in the vitality structure of cohorts and increase in their quality index; b) deterioration in the vitality structure of cohorts and decrease in their quality index; c) lack of changes in the vitality structure of cohorts and, consequently, in the quality index value.

The results of the analysis of all theoretically conceivable options for change in the vitality structure of cohorts of various categories of young generation and forest stand that correspond to different stages of natural reforestation provide the evidence of implementing different vitality tactics by certain groups of individuals. They manifest themselves in the spatial and temporal flexibility of vitality characteristics and their spatial and temporal variability. The spatial and temporal vitality flexibility is manifested in the change of values of the quality index of certain cohorts (populations) of different categories of young generation and forest stand by different hab- 
itat or in time. The spatial and temporal vitality flexibility is implemented through the change of the ratio in the composition of a cohort (population) of individuals of different vitality classes ("a", "b" and "c").

Both quantitative and qualitative aspects of the vitality flexibility implementation may be expressed by means of a specially developed index of vitality dynamics (IVD) calculated according to the following formula (1):

$$
\mathrm{IVD}=(Q n-Q p) / 0.166
$$

where $Q n$ - value of the cohort (population) quality index at the next stage of reforestation (development or gradient degree),

$Q p$ - value of the cohort (population) quality index at the previous stage of reforestation (development or gradient degree),

0.166 - value of the quality index, at the level of which populations are transferred from one quality type to the other (according to the provisions of the classical vitality analysis, a population is depressed if the value of quality index $Q$ is $0-0.166$; balanced if $Q$ is $0.167-0.332$; prosperous if $\mathrm{Q}$ is $0.333-0.50$ ).

In general, values of the index of vitality dynamics (IVD) range from -3.012 to +3.012 .

If IVD $=0$, cohorts are characterized by a lack of changes in the value of the quality index Q by the stages of natural reforestation.

If IVD (in absolute value) is less than 1, changes are insignificant.

If IVD (in absolute value) is from 1 to 2 , changes are significant.

If IVD (in absolute value) is greater than 2, changes are dramatic.

If value of IVD is with a minus, there is deterioration in the condition of a cohort (population), with a plus - its improvement.

\section{Vitality structure of the cohorts of Pinus sylvestris and its dynamics by the stages of natural reforestation}

The study of natural reforestation of $P$. sylvestris was carried out in the territory of Left-Bank Polissia of Ukraine. The information on the vitality structure of some cohorts of this species is given in Tables 1,2. The obtained results show that the species under study in forests of the Pineta sylvestris formation has the most diverse vitality structure. Here, in one group of associations there are quite often the cohorts, the state of which corresponds to all three types: depressed, balanced and prosperous, and the quality index value varies from the minimum values $(0)$ to the maximum possible $(0.5)$. This phenomenon is typical for groups of such associations as Pineta (sylvestris) 


\section{Chapter «Biological sciences»}

franguloso (alni)-vacciniosa (myrtilli) and Pineta (sylvestris) hylocomiosa. In specific forest site conditions, there are often the P. sylvestris cohorts of two quality types. Thus, a group of Pineta (sylvestris) sphagnosa associations is characterized by the variety of undergrowth that by quality indicators corresponds to the level of depressed populations and (rarely) balanced.

The $P$. sylvestris cohorts, formed under the conditions of other forest formations, do not differ in a variety of vitality types, but they may be represented by the $P$. sylvestris individuals and cohorts of high vitality. This feature is inherent in the forests of a group of Betuleta (pendulae) caricosa (pilosae) associations, which is characterized by availability of prosperous cohort of young and generative (mature) trees of $P$. sylvestris, the quality index value of which varies from 0.44 to 0.50 .

The gradient analysis has been applied in order to clarify the common patterns of changes in vitality structure and the quality index of different cohorts of $P$. sylvestris, depending on habitat conditions. The influence of moisture content, soil trophicity and density of forest stands has been studied as well.

Table 1

Vitality structure of the cohorts of small undergrowth of Pinus sylvestris

\begin{tabular}{|c|c|c|c|c|}
\hline \multirow{3}{*}{ Association groups } & \multicolumn{4}{|c|}{ Small undergrowth (Us) } \\
\hline & \multicolumn{3}{|c|}{$\begin{array}{l}\text { share of individuals } \\
\text { of different classes }\end{array}$} & \multirow{2}{*}{$\begin{array}{l}\text { quality } \\
\text { index } \\
\text { (Q) }\end{array}$} \\
\hline & $\mathbf{a}$ & $\mathbf{b}$ & $\mathbf{c}$ & \\
\hline Pineta (sylvestris) hylocomiosa & $0-0.96$ & $0-0.53$ & $0-1.0$ & $0-0.50$ \\
\hline $\begin{array}{l}\text { Pineta (sylvestris) calamagrostidosa } \\
\text { (epigeioris) }\end{array}$ & $0.20-0.25$ & $0.25-0.40$ & $0.40-0.50$ & $0.25-0.30$ \\
\hline Pineta (sylvestris) nardosa (strictae) & $0.50-0.60$ & $0.34-0.40$ & $0.06-0.10$ & $0.45-0.47$ \\
\hline $\begin{array}{l}\text { Pineta (sylvestris) franguloso (alni) - } \\
\text { vacciniosa (myrtilli) }\end{array}$ & $0.07-0.13$ & $0.07-0.53$ & $0.40-0.80$ & $0.10-0.30$ \\
\hline Pineta (sylvestris) vacciniosa (myrtilli) & $0.25-0.26$ & $0.17-0.18$ & $0.56-0.58$ & $0.21-0.22$ \\
\hline Pineta (sylvestris) sphagnosa & $0-0.18$ & $0.11-0.35$ & $0.47-0.89$ & $0.05-0.26$ \\
\hline $\begin{array}{l}\text { Querceto(roboris) - Pineta (sylvestris) } \\
\text { vacciniosa (myrtilli) }\end{array}$ & $0.1-0.17$ & $0.45-0.50$ & $0.34-0.40$ & $0.30-0.33$ \\
\hline Querceta (roboris) convallariosa (majalis) & $0.25-0.34$ & $0.32-0.50$ & $0.25-0.34$ & $0.33-0.38$ \\
\hline Betuleta (pendulae) vacciniosa (myrtilli) & $0.26-0.28$ & $0.13-0.18$ & $0.56-0.60$ & $0.21-0.22$ \\
\hline Betuleta (pendulae) stellariosa (holosteae) & $0-0.02$ & $0.64-0.65$ & $0.33-0.36$ & $0.32-0.34$ \\
\hline
\end{tabular}


Table 2

Vitality structure of the cohorts of generative trees of Pinus sylvestris

\begin{tabular}{|c|c|c|c|c|}
\hline \multirow{3}{*}{ Association groups } & \multicolumn{4}{|c|}{ Generative trees of tree layer (Tm) } \\
\hline & \multicolumn{3}{|c|}{$\begin{array}{l}\text { share of individuals } \\
\text { of different classes }\end{array}$} & \multirow[t]{2}{*}{$\begin{array}{c}\text { quality } \\
\text { index } \\
\text { (Q) }\end{array}$} \\
\hline & $\mathbf{a}$ & $\mathbf{b}$ & $\mathbf{c}$ & \\
\hline Pineta (sylvestris) hylocomiosa & $0-1.0$ & $0-1.0$ & $0-1.0$ & $0-0.5$ \\
\hline $\begin{array}{l}\text { Pineta (sylvestris) calamagrostidosa } \\
\text { (epigeioris) }\end{array}$ & $0.6-1.0$ & $0-0.3$ & $0-0.1$ & $0.45-0.5$ \\
\hline Pineta (sylvestris) nardosa (strictae) & $0.10-0.15$ & $0.36-0.77$ & $0.08-0.54$ & $0.23-0.46$ \\
\hline $\begin{array}{l}\text { Pineta (sylvestris) coryloso } \\
\text { (avellanae) - vacciniosa (myrtilli) }\end{array}$ & $0.67-0.75$ & $0.1-0.05$ & $0.2-0.32$ & $0.34-0.40$ \\
\hline Pineta (sylvestris) asarosa (europaei) & $0.64-0.67$ & $0.30-0.33$ & $0-0.06$ & $0.47-0.50$ \\
\hline $\begin{array}{l}\text { Pineta (sylvestris) franguloso (alni) - } \\
\text { vacciniosa (myrtilli) }\end{array}$ & $0-0.88$ & $0-0.57$ & $0-1.0$ & $0-0.5$ \\
\hline Pineta (sylvestris) vacciniosa (myrtilli) & $0.41-0.48$ & $0.37-0.46$ & $0.06-0.22$ & $0.39-0.47$ \\
\hline Pineta (sylvestris) moliniosa (caeruleae) & $0.8-1.0$ & $0-0.2$ & $0-0.10$ & $0.45-0.50$ \\
\hline Pineta (sylvestris) sphagnosa & $0-0.16$ & $0-0.28$ & $0.56-1.0$ & $0-0.22$ \\
\hline $\begin{array}{l}\text { Querceto (roboris) - Pineta (sylvestris) } \\
\text { vacciniosa (myrtilli) }\end{array}$ & $0.67-1.0$ & $0-0.33$ & $0-0.1$ & $0.45-0.50$ \\
\hline $\begin{array}{l}\text { Querceto (roboris) - Pineta (sylvestris) } \\
\text { corylosa (avellanae) sparsi herbosa }\end{array}$ & $0.05-0.07$ & $0.67-0.93$ & $0.02-0.26$ & $0.37-0.49$ \\
\hline $\begin{array}{l}\text { Betuleto (pendulae) - Pineta } \\
\text { (sylvestris) vacciniosa (myrtilli) }\end{array}$ & $0-0.67$ & $0-0.11$ & $0.22-1.0$ & $0-0.39$ \\
\hline $\begin{array}{l}\text { Tilieto (cordatae) - Querceta (roboris) } \\
\text { stellariosa (holosteae) }\end{array}$ & $0.01-0.02$ & $0.87-0.88$ & $0.12-0.10$ & $0.44-0.45$ \\
\hline Betuleta (pendulae) caricosa (pilosae) & $0-0.03$ & $0.91-1.0$ & $0-0.06$ & $0.47-0.50$ \\
\hline Populeta (tremulae) stellariosa (holosteae) & $0.88-1.0$ & $0-0.06$ & $0-0.06$ & $0.47-0.5$ \\
\hline
\end{tabular}

It is found that within the P. sylvestris cohorts the share of individuals of highest vitality classes ("a" and "b") and, accordingly, values of the quality index increase with the improvement in soil fertility. The limiting effect of low soil fertility on the vitality of $P$. sylvestris is most clearly manifested in the Pineta sylvestris formation.

The increase in canopy density (from 0.4 and above) results in an increase in the share of plants of the lowest vitality (class "c") in cohorts and a decrease in the quality index. The habitat of vast number of groups, in which $P$. sylvestris cohorts are characterized by the recorded highest val- 
ues of the quality index $(\mathrm{Q}=0.4-0.5)$, has canopy density at the level of 0.4-0.5. Among the phytocoenoses under study, the representatives of a group of Pineta (sylvestris) hylocomiosa associations are characterized by the most substantial variation in canopy density (from 0.4 to 1.0). The formation of gaps ( $50 \mathrm{~m} 2$ or more in area) in the canopy of forest stand is the most common in this group of associations. These features of the horizontal structure of forest communities is one of the reasons that the P. sylvestris cohorts, represented as part of a group of Pineta (sylvestris) hylocomiosa associations, are characterized by a significant variety of vitality structure and the maximum possible variation in values of the quality index.

On the soil moisture gradient, the most significant decrease in the vitality level of all P. sylvestris cohorts is observed in the water-logged places, as well as in the areas with insufficient moisture. A glaring example of the limiting effect of high moisture content on the vitality state of $P$. sylvestris cohorts is, first and foremost, the habitat of a group of Pineta (sylvestris) sphagnosa associations.

Small undergrowth is characterized by deterioration in the vitality structure, manifested in an increase in the share of individuals of class "c" and a decrease in the quality index value, which is well-pronounced in forest communities with dense and high grass cover, as in the group of Pineta (sylvestris) calamagrostidosa (epigeioris) associations.

$P$. sylvestris cohorts in different habitat have specific features of the qualitative composition and vitality level. From the perspective of disclosure of the main features, natural reforestation patterns, including the dynamics of vitality parameters of forest-forming species, the phytocoenoses with complete recovery (Isp-Usml-Tym model) are the most stable. However, the process of forest phytocoenosis self-renewal, which corresponds to this model, in forests of the region under study is observed in a very limited number of groups of associations, in particular, Pineta (sylvestris) hylocomiosa.

The results of the study of changes in the quality index value of $\mathrm{P}$. sylvestris cohorts are illustrated in Fig. 1. In the case of complete natural reforestation by the stages of this process, there is a change in the vitality structure of cohorts and their quality index, that is, both vitality flexibility and vitality variability are observed. Typical is the absence of clearly expressed single-vector trends of changes in values of the quality index at the stages of natural reforestation. It is also characterized by the "critical" 
transitions, at the level of which there is a significant (both from the quantitative and qualitative points of view) change in values of the quality index, that is, its significant reduction or increase.

In general, a significant number of association groups are dominated by a decrease in the quality index values during the transition of cohorts from the previous to the next stage of recovery. This reduction mainly occurs against a decrease in the "quality" status of cohorts. This general trend is also confirmed by the data shown in Table 3. The complete natural reforestation of $P$. sylvestris occurs not only in a group of Pineta (sylvestris) hylocomiosa associations, but also in some others (for example, Pineta (sylvestris) franguloso (alni)-vacciniosa (myrtilli) and Pineta (sylvestris) sphagnosa) (Table 4), that is, in forest phytocoenoses, which differ significantly in ecological and coenotic characteristics.

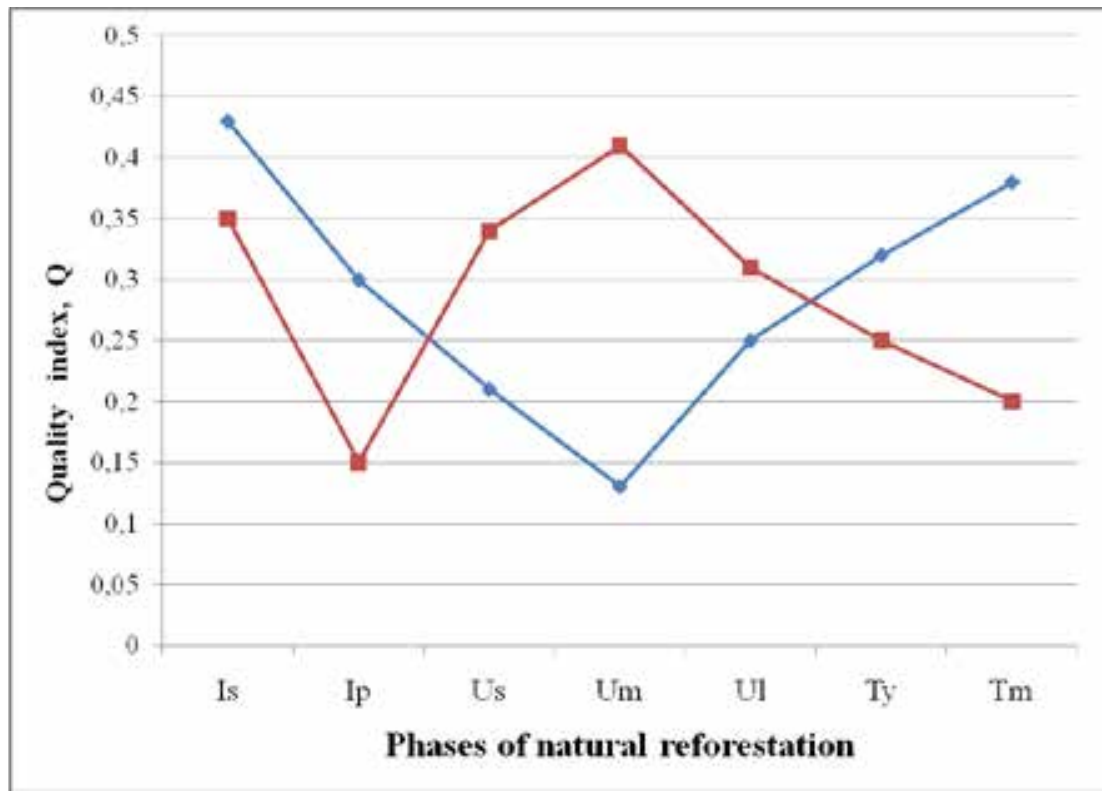

Figure 1. Changes in the quality index of Pinus sylvestris cohorts in the two phytocoenoses of a group of Pineta (sylvestris) hylocomiosa associations at the stages of complete natural reforestation (I-Usml-Tym model) 
Value of the index of vitality dynamics (IVD) and change in the qualitative type of Pinus sylvestris cohorts by the stages of complete natural reforestation in the phytocoenoses of a group of Pineta (sylvestris) hylocomiosa associations (Isp-Usml-Tym model) ${ }^{1}$

\begin{tabular}{|c|c|c|c|c|c|c|c|}
\hline \multirow{2}{*}{$\begin{array}{l}\text { Ser. } \\
\text { No. }\end{array}$} & \multirow{2}{*}{\begin{tabular}{|c|}
$\begin{array}{c}\text { Phytocenoses } \\
\text { of association } \\
\text { groups }\end{array}$ \\
\end{tabular}} & \multicolumn{6}{|c|}{ Transition by the stages of natural reforestation } \\
\hline & & Is $\rightarrow$ Ip & $\mathrm{Ip} \rightarrow \mathrm{Us}$ & $\mathbf{U s} \rightarrow \mathbf{U m}$ & $\mathbf{U} \mathbf{m} \rightarrow \mathbf{U l}$ & $\mathbf{U I} \rightarrow \mathbf{T y}$ & $\mathbf{T y} \rightarrow \mathbf{T m}$ \\
\hline \multirow[b]{2}{*}{1} & \multirow{2}{*}{$\begin{array}{l}\text { Pineta } \\
\text { (sylvestris) } \\
\text { hylocomiosa }\end{array}$} & -0.7831 & -0.5422 & -0.6024 & 0.8434 & 0.3614 & 0.3614 \\
\hline & & $\mathrm{P} \rightarrow \mathrm{B}$ & B-B & $B \rightarrow D$ & $D \rightarrow B$ & B-B & $\mathrm{B} \rightarrow \mathrm{P}$ \\
\hline \multirow{2}{*}{2} & \multirow{2}{*}{\begin{tabular}{|l|} 
Pineta \\
(sylvestris) \\
hylocomiosa
\end{tabular}} & -1.2651 & 1.0843 & 0.4819 & -0.5422 & -0.3614 & -0.3012 \\
\hline & & $\mathrm{P} \rightarrow \mathrm{D}$ & $\mathrm{D} \rightarrow \mathrm{B}$ & $B \rightarrow P$ & $\mathrm{P} \rightarrow \mathrm{B}$ & B-B & B-B \\
\hline
\end{tabular}

Note: In this and similar tables for each group of associations (groups), values of the index of vitality dynamics (IVD) are given in the first line, data on changes in the qualitative type of cohort - in the first line. Letters denote: D - depressed cohort, $\mathrm{B}$ - balanced, $\mathrm{P}$ - prosperous.

Table 4

Value of the index of vitality dynamics (IVD) and change in the qualitative type of Pinus sylvestris cohorts by the stages of complete natural (I-Usml-Tym model)

\begin{tabular}{|l|c|c|c|c|}
\hline \multirow{2}{*}{$\begin{array}{c}\text { Phytocenoses of association } \\
\text { groups }\end{array}$} & \multicolumn{4}{|c|}{ Transition by the stages of natural reforestation } \\
\cline { 2 - 5 } & $\mathbf{U s} \rightarrow \mathbf{U m}$ & $\mathbf{U m} \rightarrow \mathbf{U l}$ & $\mathbf{U l} \rightarrow \mathbf{T y}$ & $\mathbf{T y} \rightarrow \mathbf{T m}$ \\
\hline \multirow{2}{*}{$\begin{array}{c}\text { Pineta (sylvestris) franguloso } \\
\text { (alni)- vacciniosa (myrtilli) }\end{array}$} & -0.24096 & 1.20482 & -1.26506 & 1.32530 \\
\cline { 2 - 5 } & $\mathrm{D}-\mathrm{D}$ & $\mathrm{D} \rightarrow \mathrm{B}$ & $\mathrm{B} \rightarrow \mathrm{D}$ & $\mathrm{D} \rightarrow \mathrm{B}$ \\
\hline \multirow{2}{*}{ Pineta (sylvestris) sphagnosa } & -0.54217 & -0.1205 & -0.6024 & 0 \\
\cline { 2 - 5 } & $\mathrm{B}-\mathrm{B}$ & $\mathrm{B} \rightarrow \mathrm{D}$ & $\mathrm{D}-\mathrm{D}$ & $\mathrm{D}-\mathrm{D}$ \\
\hline
\end{tabular}

In general, when individuals of a new generation of forest-forming species reach the tree layer, the volume, diversity and power of direct interaction and competition between them and the parent forest stand often increase. Therefore, it is no coincidence that at the stage of formation of young tree cohorts there is often a significant decrease in values of the quality index. In the forests that are in the system of economic use, due to the application of forest management measures, the transition of young plants to the first tree layer and their achievement of generative maturity 
can be significantly accelerated, and often followed by an improvement in the vitality of young trees.

The steady reforestation is mainly characterized by the manifestation of vitality flexibility (change in values of the quality index by cohorts) and vitality variability (change in the relationship between shares of plants of different vitality classes within cohorts). In general, a reduction in the quality index values under the transition from the previous cohort to the next one is predominant (in $58.3 \%$ of cases).

This indicator may vary significantly by association groups: it amounts to $50 \%$ in Pineta (sylvestris) franguloso (alni)-vacciniosa (myrtilli) and Pineta (sylvestris) hylocomiosa, and $75 \%$ in Pineta (sylvestris) sphagnosa. In all association groups under study, a decrease in the quality index values was mainly (in $41.7 \%$ of cases) insignificant (less than 1 in the absolute value of IVD) and accompanied by both the transition of populations from one qualitative type to the other, and changes in indicators within one type of populations. No improvement in cohort vitality by the stages of natural reforestation in a group of Pineta (sylvestris) sphagnosa associations has been registered, whereas it occurs in the groups of Pineta (sylvestris) franguloso (alni)-vacciniosa (myrtilli) and Pineta (sylvestris) hylocomiosa associations. An increase in values of the quality index was significant mainly (in $75 \%$ of cases) with the value of the index of vitality dynamics (IVD) amounting to $1.2-1.3$ and accompanied by the transition of cohorts from one quality type to the other (from the category of depressed cohorts to the category of balanced ones or from the category of balanced cohorts to the category of prosperous ones).

The associations, where $P$. sylvestris does not take place in the formation of the first tree layer, are characterized by the incomplete natural reforestation when the young generation of this species reaches the tree layer but has no ability for generative propagation (I-Usml-Ty model) (Table 5). In a group of Betuleta (pendulae) vacciniosa (myrtilli) associations, each of "transitions" by the stages of natural reforestation is accompanied by a significant change in vitality structure, values of the quality index and vitality type of cohorts. There is the manifestation of both vitality flexibility and vitality variability.

The process of natural reforestation of $P$. sylvestris often terminates at the stage of large undergrowth formation (I-Usml model). It occurs in the pine forests that by the vitality structure belong to different quality types. 
Value of the index of vitality dynamics (IVD) and change in the qualitative type of Pinus sylvestris cohorts by the stages of incomplete natural reforestation (I-Usml-Ty model)

\begin{tabular}{|l|c|c|c|}
\hline \multirow{2}{*}{$\begin{array}{c}\text { Phytocenoses } \\
\text { of the association group }\end{array}$} & \multicolumn{3}{|c|}{$\begin{array}{c}\text { Transition by the stages } \\
\text { of natural reforestation }\end{array}$} \\
\cline { 2 - 4 } & Us $\rightarrow \mathbf{U m}$ & $\mathbf{U m} \rightarrow \mathbf{U l}$ & $\mathbf{U l} \rightarrow \mathbf{T y}$ \\
\hline $\begin{array}{l}\text { Betuleta (pendulae) vacciniosa } \\
\text { (myrtilli) }\end{array}$ & -1.20482 & 3.012 & -3.012 \\
\cline { 2 - 4 } & $\mathrm{B} \rightarrow \mathrm{D}$ & $\mathrm{D} \rightarrow \mathrm{P}$ & $\mathrm{P} \rightarrow \mathrm{D}$ \\
\hline
\end{tabular}

In all groups of associations of Pineta sylvestris formation, where natural reforestation is consistent with this model, the lowest values of the quality index of $P$. sylvestris cohorts are recorded in the cohort, which is "final" in the above model - that is, at the level of large undergrowth.

In the cases where natural reforestation corresponds to the I-Usml model, the vitality structure of cohorts and their quality index change by its stages (Table 6). The value of the latter characteristic often increases during the transition from small to medium undergrowth and decreases during the transition from medium to large that is accompanied by the transition of cohorts from the category of prosperous to the category of depressed.

In the phytocoenoses of Pineta sylvestris formation, there is the incomplete natural reforestation, which terminates at the level of medium undergrowth (I-Usm model). This model is also applied to the natural reforestation occurring in the forests without $P$. sylvestris in the tree layer. The decrease in the quality index of $P$. sylvestris cohort during the transition from the category of small to the category of medium undergrowth is typical (Table 7).

Table 6

Value of the index of vitality dynamics (IVD) and change in the qualitative type of Pinus sylvestris cohorts by the stages of incomplete natural reforestation (I-Usml model)

\begin{tabular}{|c|c|c|}
\hline $\begin{array}{c}\text { Phytocenoses of the association } \\
\text { group }\end{array}$ & \multicolumn{2}{|c|}{$\begin{array}{c}\text { Transition by the stages of natural } \\
\text { reforestation }\end{array}$} \\
\cline { 2 - 3 } & $\mathbf{U s} \rightarrow \mathbf{U m}$ & $\mathbf{U m} \rightarrow \mathbf{U I}$ \\
\hline \multirow{2}{*}{ Pineta (sylvestris) hylocomiosa } & 0.903614 & -1.80723 \\
\cline { 2 - 3 } & $\mathrm{B} \rightarrow \mathrm{P}$ & $\mathrm{P} \rightarrow \mathrm{D}$ \\
\hline
\end{tabular}


Value of the index of vitality dynamics (IVD) and change in the qualitative type of Pinus sylvestris cohorts by the stages of incomplete natural reforestation (I-Usm model)

\begin{tabular}{|c|c|}
\hline Phytocenoses of association groups & $\begin{array}{c}\text { Transition by the stages } \\
\text { of natural reforestation } \\
\text { Us } \rightarrow \text { Um }\end{array}$ \\
\hline \multirow{2}{*}{ Pineta (sylvestris) sphagnosa } & -0.55241 \\
\hline & D-D \\
\hline \multirow{2}{*}{ Pineta (sylvestris) calamagrostidosa (epigeioris) } & -1.50602 \\
\hline & $\mathrm{B} \rightarrow \mathrm{D}$ \\
\hline \multirow{2}{*}{ Pineta (sylvestris) calamagrostidosa (epigeioris) } & -0.3012 \\
\hline & B-B \\
\hline \multirow{2}{*}{$\begin{array}{l}\text { Pineta (sylvestris) franguloso (alni) - vacciniosa } \\
\text { (myrtilli) }\end{array}$} & -0.51145 \\
\hline & D-D \\
\hline \multirow{2}{*}{ Pineta (sylvestris) hylocomiosa } & -2.78012 \\
\hline & $\mathrm{P} \rightarrow \mathrm{D}$ \\
\hline \multirow{2}{*}{ Pineta (sylvestris) hylocomiosa } & -0.06024 \\
\hline & $\mathrm{P}-\mathrm{P}$ \\
\hline \multirow{2}{*}{ Pineta (sylvestris) hylocomiosa } & -2.63554 \\
\hline & $\mathrm{P} \rightarrow \mathrm{D}$ \\
\hline \multirow{2}{*}{ Pineta (sylvestris) hylocomiosa } & -1.94277 \\
\hline & $\mathrm{B} \rightarrow \mathrm{D}$ \\
\hline \multirow{2}{*}{ Pineta (sylvestris) hylocomiosa } & -0.20843 \\
\hline & $\mathrm{P}-\mathrm{P}$ \\
\hline \multirow{2}{*}{ Pineta (sylvestris) hylocomiosa } & -2.00783 \\
\hline & $\mathrm{P} \rightarrow \mathrm{B}$ \\
\hline \multirow{2}{*}{ Pineta (sylvestris) hylocomiosa } & -0.53795 \\
\hline & $B \rightarrow D$ \\
\hline \multirow{2}{*}{ Pineta (sylvestris) hylocomiosa } & -2.48072 \\
\hline & $\mathrm{P} \rightarrow \mathrm{D}$ \\
\hline \multirow{2}{*}{ Pineta (sylvestris) nardosa (strictae) } & -1.56627 \\
\hline & $\mathrm{P} \rightarrow \mathrm{B}$ \\
\hline \multirow{2}{*}{ Pineta (sylvestris) vacciniosa (myrtilli) } & -1.26506 \\
\hline & $\mathrm{B} \rightarrow \mathrm{D}$ \\
\hline \multirow{2}{*}{ Betuleta (pendulae) stellariosa (holosteae) } & -1.91687 \\
\hline & $\mathrm{B} \rightarrow \mathrm{D}$ \\
\hline
\end{tabular}


In $37.5 \%$ of cases, the decrease in values of the index $Q$ is insignificant and occurs "within" one quality type. The cases of significant and dramatic reduction of indicators are equally (by $31.3 \%$ ) represented. All of them are accompanied by a change in the quality type of cohorts. There is (in $25 \%$ of cases) the transition of populations from the category of prosperous to the category of depressed. The change in the vitality structure of undergrowth in the implementation of I-Usm model in the forests of Pineta sylvestris formation does not show a clear and unambiguous dependence on the level of vitality of the parent forest stand.

In the forests of Left-Bank Polissia of Ukraine, natural reforestation often terminates at the level of small undergrowth (I-Us model). At the same time, the cohorts of generative trees being in the composition of parent forest stands, are characterized by the quality index values in the range of $0-0.5$, and the cohorts of small undergrowth $-0.06-0.40$. The above range of indicators corresponds to all three quality types of cohorts: from depressed to prosperous.

Prosperous cohorts of small undergrowth are mainly recorded in the forests, the stand of which is formed from prosperous cohorts. However, there are the cases, where small undergrowth with a significant share $(60 \%)$ of individuals of vitality class " $a$ " is found in the canopy of forest stand of a depressed type.

In a number of communities (a group of Pineta (sylvestris) coryloso (avellanae)-vacciniosa (myrtilli), Pineta (sylvestris) asarosa (europaei) associations, etc.), despite the fact that they contain the generative trees of $P$. sylvestris, there is no sustainable natural reforestation of this species. The undergrowth is often not formed even in the forests, where stands are dominated by individuals of vitality class " $a$ ", and the cohorts of generative plants belong to the category of prosperous.

The last fact shows that a single factor of high quality of the parent forest stand is not always decisive for the successful natural reforestation. This statement is to some extent consistent with the results of evaluation of the correlation relationship between the values of the quality index of different cohorts of $P$. sylvestris presented in different forest phytocoenoses.

The strength and nature of the correlation relationship between the values of the quality index of different cohorts were very variable and ambiguous. Thus, the value of the correlation relationship between the quality index of small undergrowth and the parent forest stand varies from -0.41 to 
+0.70 , and the value of the correlation relationship between the quality index of medium undergrowth and generative trees - from $-0.34+0.63$.

\section{Conclusions}

The paper presents some results of the studies of features and patterns of the natural reforestation process conducted for more than ten years, on the basis of which:

1. The system of division of young generation of forest-forming species into the seven categories and the method of selecting intra-population groups - cohorts is developed.

2. The generalizing models of the natural reforestation process, which serve as the basis for unification of the study of dynamics of the key population characteristics by its stages, are formed.

3. It is shown that the assessment of the vitality structure of forest-forming species cohorts against the application of different models, is supplemented by the analysis of vitality variability and flexibility, enables to consider the process of self-recovery of forest communities in its dynamics by covering the entire cycle of reforestation (from seed formation by individuals of the upper layer of communities to their replacement by the trees of a new generation) and to get a holistic view of this process.

4. It is proved on the example of the natural reforestation of $P$. sylvestris in the conditions of Left-Bank Polissia of Ukraine that in various models of natural reforestation the vitality cohort structure acts as a separate and very dynamic characteristic. The change in the characteristic features of the vitality structure by the stages of natural reforestation in P. sylvestris is very diverse. The dynamics of vitality structure is manifested in the wide implementation of its spatial and temporal variability and flexibility.

5.P. sylvestris is dominated by the models of incomplete natural reforestation (I-Usml-Ty, I-Usml, I-Usm, I-Us, I models). The correspondence of this process in pine forests to such models is often a consequence, firstly, of fluctuations in quantitative and qualitative indicators of seed productivity over the years, and secondly, of the absence of conditions favorable for the formation and development of the young generation of this species under the canopy of a number of parent forest stands. The predominance of artificially created pine forests with high density in the territory of Left-Bank Polissia of Ukraine is one of the factors that have a negative impact on the vitality structure of the cohorts of the young generation of $P$. sylvestris. 
6. Despite the fact that cohorts of $P$. sylvestris of different groups of associations vary significantly by vitality parameters, the change in values of the quality index and vitality structure on simple gradients of leading ecological-coenotic factors (density of forest stands, soil trophicity and moisture, projective cover of the herbaceous and subshrub layer, etc.) there are clearly defined patterns. The vitality parameters of $P$. sylvestris cohorts are a response to the influence of a number of ecological and coenotic factors inherent in a particular habitat.

The prospect of further scientific work is the application of vitality analysis and the approaches proposed and tested in this work to assess the status of natural reforestation with the participation of other major forest-forming types: Quercus robur L., Acer platanoides L., Betula pendula Roth., Populus tremula L., etc.

\section{References:}

1. Zlobin Yu.A. (1989). Theory and practice of evaluation of vitality composition of plant coenopopulations. Botanical Journal, 74(6): 769-78.

2. Zlobin Yu.A. (2009). Population ecology of plants: current state, growth areas. Sumy: University Book.

3. Zlobin Yu.A. (2018). Algorithm for assessing the vitality of plant individuals and the vitality structure of phytopopulations. Chernomorsk. Botanical Journal, 14(3): 213-226.

4. Pasternak P.S., Romanov N.B. (1975). Renewal of flat forests in the Ukrainian SSR. Forest Renewal: 214-215.

5. Sannikov S.N., Sannikova N.C. (1985). Ecology of natural pine regeneration under the forest canopy. M.: Nauka.

6. Skliar V.H. (2013). Dynamics of vitality parameters of forest-forming species of Novgorod-Siversk Polissia: theoretical bases and methods of evaluation. Ukrainian Botanical Journal, 70(5): 624-629.

7. Chapin III.F., Matson P. \& Mooney H. (2011). Principles of terrestrial ecosystems ecology. Springer.

8. Connel J.H. (1989). Some processes affecting the species composition in forest gaps. Ecology, 70 (3): 560-562.

9. Horn H.S. (1975). Forest succession. Sci. Amer., 232(5): 90-98.

10. Seymour A. \& Hunter M. (1999). Principles of ecological forestry. Maintaining Biodiversity in Forest Ecosystems. Cambridge Univ. Press: 22-61.

11. Ward J.S. \& Worthley T.E. (2004). Forest regeneration handbook. USA Forest N., E. Area. 


\title{
CHAPTER «VETERINARY COMMUNICATIONS»
}

\author{
PREDICTION OF COMFORT \\ FOR DAIRY COWS, DEPENDING ON THE STATE \\ OF THE ENVIRONMENT AND THE TYPE OF BARN
}

\author{
Mylostyvyi Roman ${ }^{1}$ \\ Chernenko Oleksandr ${ }^{2}$ \\ Lisna Alisa ${ }^{3}$
}

DOI: https://doi.org/10.30525/978-9934-571-78-7_53

\begin{abstract}
Material and resource conservation are important when choosing the optimal technology for keeping dairy cattle. The so-called "Canadian technologies" of frame construction that are widely used in the world are only relatively recently used in national animal husbandry. The question of ensuring the comfort of animals in such rooms remains controversial, since the climate in them is as close as possible to environmental conditions. The purpose of the study was to study the temperature and humidity regime of uninsulated rooms and assess the state of comfort of animals in barns of the frame and hangar type. The temperature and humidity of the air were measured inside and outside the premises $(\mathrm{n}=827)$ periodically from January to July 2018 (in the temperature range from -7.8 to $+34.2{ }^{\circ} \mathrm{C}$ ). Using the multiple linear regression function in STATISTICA 10 (StatSoft, Inc., 2011), the calculated temperature values in the barns for low and high temperatures of the Steppe of Ukraine were obtained. It has been established that the temperature-humidity regime of uninsulated rooms is as close as possible to the state of the external environment and depends on the design features (type) of the barn.
\end{abstract}

\footnotetext{
${ }^{1}$ Candidate of Veterinary Sciences, Associate Professor,

Associate Professor of the Department of Technology for Processing Livestock Products,

Dnipro State Agrarian and Economic University, Ukraine

${ }^{2}$ Doctor of Agricultural Sciences, Associate Professor,

Professor of the Department of Technology of Animal Feeding and Breeding,

Dnipro State Agrarian and Economic University, Ukraine

${ }^{3}$ Postgraduate Student,

Dnipro State Agrarian and Economic University, Ukraine
} 


\section{Chapter «Veterinary communications»}

The temperature difference inside and outside the premises will be $3-5^{\circ} \mathrm{C}$. It is necessary to provide additional space cooling (axial fans of large diameter, small-drop irrigation, as well as their combination), since the temperature-humidity index (THI) inside the barn will be 2-3 units higher. The material of the article will be useful for breeders when choosing a technology for keeping dairy cows. Calculated values of temperatures and THI in uninsulated rooms of frame and hangar type can be used as approximate data for assessing the comfort of cows in lightweight rooms in conditions of temperate continental climate of the Steppe of Ukraine. The values of temperature and relative humidity of air in the barns obtained by us, as well as the temperature-humidity index (as an indicator of the comfort of animals in hot conditions), require practical confirmation under conditions of extreme high and low ambient temperatures. This will be the material for our further research, as well as the influence of climate in the barn on the physiological state and productivity of dairy cows.

\section{Introduction}

The environment has a significant impact on the physiological state, behavior and productivity of dairy cows [25, p. 1; 26, p. 705; 28, p. 1623]. This should be taken into account when creating comfortable conditions for animals, protecting them from extreme high and low temperatures [2, p. 81]. The boundaries of temperature comfort for livestock are very small and depend on the breed and animal productivity [12, p. 1675]. Comfortable for cows are temperatures from +5 to $+20^{\circ} \mathrm{C}[5, \mathrm{p}$. 5]. According to some data, temperatures ranging from $-34^{\circ} \mathrm{C}[1, \mathrm{p} .481]$ to $+25^{\circ} \mathrm{C}[22$, p. 2407$]$ will be acceptable for livestock. In any case, only in good conditions animals can fully realize their productive potential.

The way of keeping dairy cows in each case is selected based on climatic, economic and industrial conditions. In Ukraine, capital buildings (cowsheds) are mainly built for keeping livestock in the cold period of the year and light canopies to protect animals from heat and precipitation during grazing. And only in recent decades, frame construction of premises made of metal structures has become widespread in animal husbandry. Such modern wide-sized barns are equipped with side curtains, aft table, cow boxes and a light-emitting comb [21, p. 41]. Researchers [33, p. 74] believe that they are most comfortable for highly productive animals when kept in barns all year round. 
The microclimate of such premises largely depends on the environmental conditions. Moreover, the temperature difference inside and outside the barn is minimal $[13$, p. $25 ; 21$, p. $41 ; 24$, p. 305] and they directly affect animals [2, p. 81]. Reports by authors [21, p. 41; 32, p. 37; 35, p. 225] are only partially devoted to the study of climate in uninsulated rooms. They cover, as a rule, only one of the seasons of the year, taking into account short-term measurements of the state of the air environment in the barn. This limits the ability to build accurate mathematical models of climate prediction in animal rooms due to a small sample.

The one-sided approach remains to assessing the influence of air on the physiological state and productivity of cows. Since the temperature and relative humidity of the air are taken into account without their joint influence on the organism of animals. Whereas the temperature and humidity index (THI) has long been considered to be a fairly reliable criterion for assessing the comfort of animals $[9, \mathrm{p} .1]$. At the same time, the ongoing search for new solutions to assess the impact of the external environment on the welfare of dairy cattle continues [10].

The aim of the work was to assess the state of animal comfort in uninsulated cowsheds of various types in a temperate climate of the Steppe of Ukraine. This involved multiple measurements of temperature and relative humidity of air outside and inside barns (for building linear regression models), forecasting temperature and humidity in rooms at high and low ambient temperatures, and calculating the value of temperaturehumidity index in rooms as a criterion for evaluating comfort cows in heat.

\section{Materials and methods}

The study was conducted in cowsheds of a monoblock dairy complex of the private joint-stock company Agro-Soyuz of the Dnipropetrovs'k region from January to June 2018. The temperature and humidity conditions of different types of rooms were studied. The cowshed carcass type (CCT) is made of metal structures (without roof insulation), and in a cowshed hangar type (CHT) with a canopy in the form of an awning (Figure 1).

These wide-sized cowsheds have side tarpaulin curtains, they have, respectively, six- and four-row stalls for dairy cows without a leash. The premises are equipped with aft tables and group automatic drinkers. The design features of these premises are described in detail earlier $[33$, p. 74$]$. The temperature and relative humidity of the air were measured 

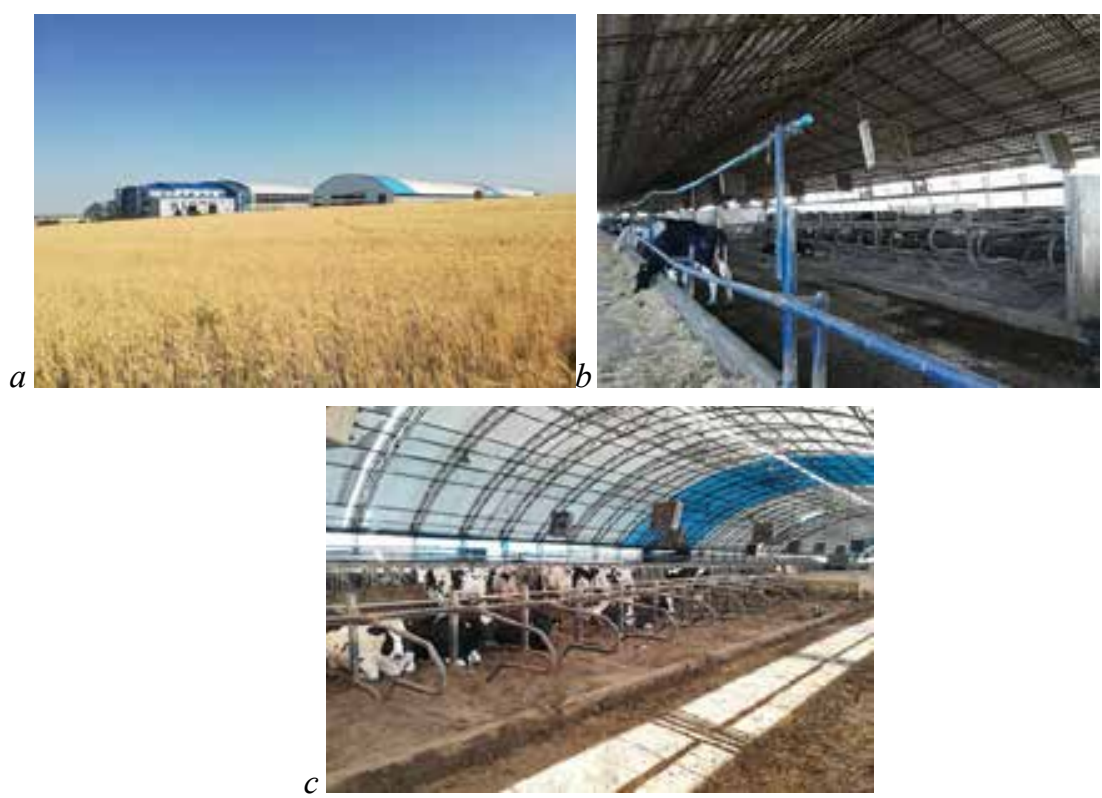

Figure 1. Monoblock of the dairy complex with uninsulated rooms of different types ( $a$ - the appearance of the dairy complex; $b$ - cowshed carcass type; $c$ - cowshed hangar type)

by a professional Benetech GM 1360 thermohygrometer outside and inside the CCT $(n=334)$ and CHT $(n=493)$ in the sides and central stall at the level of animal rest. The state of the environment at the location of the dairy complex during the heat was predicted on the basis of historical data from the meteorological report for 2017 (https://meteo.ua/). The measurements were carried out taking into account the temperature and humidity of the air at a time $(n=1924)$ within the temperature range of $+20 \ldots+37^{\circ} \mathrm{C}$. The data obtained were used to construct linear regression models using the built-in statistical functions of the STATISTICA 10 software (StatSoft, Inc., 2011).

\section{Climate prediction in uninsulated cowsheds} of different types depending on the state of the environment

The data obtained indicate that the climate in the barns is directly dependent on the state of the external environment. Outside air temperatures 
during the study period varied from $-7.5^{\circ} \mathrm{C}$ to $+34.2^{\circ} \mathrm{C}$. The correlation between temperature and relative humidity outside and inside CCT was respectively $r=0.997\left(\mathrm{R}^{2}=0.99\right)$ and $\mathrm{r}=0.955\left(\mathrm{R}^{2}=0.91\right)(\mathrm{P}<0.01)$. The relationship between temperature and humidity inside the CHT and outside was respectively $r=0.997\left(R^{2}=0.99\right)$ and $r=0.965\left(R^{2}=0.93\right)$ $(\mathrm{P}<0.01)$. This made it possible to predict the temperature and humidity conditions in uninsulated barns of various types (Table 1 and Table 2).

In this case, the linear regression equations for calculating the temperature and relative humidity of air in uninsulated cowsheds of various types were such

$$
\begin{aligned}
T_{C C T} & =2.532533+0.878064 \times T \\
R H_{C C T} & =15.03246+0.77416 \times R H \\
T_{C H T} & =2.103149+0.902499 \times T \\
R H_{C H T} & =6.107011+0.922974 \times R H
\end{aligned}
$$

where $T_{C C T}-$ temperature in the cowshed carcass type, ${ }^{\circ} \mathrm{C}$

$T_{C H T}$ - temperature in the cowshed hangar type, ${ }^{\circ} \mathrm{C}$

$R H_{C C T}$ - relative humidity in the cowshed carcass type, \%

$R H_{C H T}$ - relative humidity in the cowshed hangar type, \%

$T$ - ambient temperature, ${ }^{\circ} \mathrm{C}$

$\mathrm{RH}$ - ambient relative humidity, \%

Estimates suggest that the temperature in the premises of lightweight construction as close as possible to the indicators of the external environment (Fig. 2). The difference between external and internal temperatures in conditions of the lowest possible ambient temperature $\left(-25^{\circ} \mathrm{C}\right)$, depending on the type of cowshed, will be from 4.5 to $5.6^{\circ} \mathrm{C}$. In conditions of heat $\left(+46^{\circ} \mathrm{C}\right)$, the temperature difference will be from 2.4 to $3.1^{\circ} \mathrm{C}$. At a temperature of $+21.0-22.0^{\circ} \mathrm{C}$, the temperature inside and outside the premises will be the same.

Therefore, the design features of the of the rooms carcass and hangar type contribute to the preservation of the air temperature in the cowsheds when lowering the external temperatures below $+21.0^{\circ} \mathrm{C}$ and, conversely, as they rise above $+22.0^{\circ} \mathrm{C}$, the roof of the barns acts as a shadow protection of animals from direct sunlight and contributes to maintaining coolness.

The relative humidity inside the rooms to a greater extent than the temperature will depend on the design features of the rooms. It is calculated that the difference in this indicator between the environment and CCT will 


\section{Table 1}

\section{Calculated values of temperature in cowsheds} of various types depending on external temperature

\begin{tabular}{|c|c|c|c|c|c|c|c|c|c|}
\hline \multirow[t]{2}{*}{$\mathbf{T}$} & \multicolumn{2}{|c|}{$\begin{array}{c}\text { Cowshed } \\
\text { carcass type, } \\
n=334\end{array}$} & \multicolumn{2}{|c|}{$\begin{array}{c}\text { Cowshed } \\
\text { hangar type, } \\
n=493\end{array}$} & \multirow[t]{2}{*}{$\mathbf{T}$} & \multicolumn{2}{|c|}{$\begin{array}{c}\text { Cowshed } \\
\text { carcass type, } \\
n=334\end{array}$} & \multicolumn{2}{|c|}{$\begin{array}{c}\text { Cowshed hangar } \\
\text { type, } n=493\end{array}$} \\
\hline & $\mathbf{T}_{\text {СCT }}$ & $\begin{array}{c}+- \\
\text { toward T }\end{array}$ & $\mathbf{T}_{\text {Снт }}$ & $\begin{array}{c}+/- \\
\text { toward T }\end{array}$ & & $\mathbf{T}_{\text {CCT }}$ & \begin{tabular}{|c|}
$+/-$ \\
toward T
\end{tabular} & $\mathbf{T}_{\text {СHT }}$ & $\begin{array}{c}+/- \\
\text { toward T }\end{array}$ \\
\hline-25 & -19.4 & +5.6 & -20.5 & +4.5 & 11 & 12.2 & +1.2 & 12.0 & +1.0 \\
\hline-24 & -18.5 & +5.5 & -19.6 & +4.4 & 12 & 13.1 & +1.1 & 12.9 & +0.9 \\
\hline-23 & -17.7 & +5.3 & -18.7 & $\begin{array}{r}+4.3 \\
\end{array}$ & 13 & 13.9 & +0.9 & $\begin{array}{l}13.8 \\
\end{array}$ & +0.8 \\
\hline-22 & -16.8 & +5.2 & -17.8 & +4.2 & 14 & 14.8 & +0.8 & 14.7 & +0.7 \\
\hline-21 & -15.9 & +5.1 & -16.8 & +4.2 & 15 & 15.7 & +0.7 & 15.6 & +0.6 \\
\hline-20 & -15.0 & +5.0 & \begin{tabular}{|l}
-15.9 \\
\end{tabular} & $\begin{array}{r}+4.1 \\
\end{array}$ & 16 & 16.6 & +0.6 & 16.5 & +0.5 \\
\hline $\begin{array}{l}-19 \\
\end{array}$ & -14.2 & $\begin{array}{l}+4.8 \\
\end{array}$ & -15.0 & $\begin{array}{l}+4.0 \\
\end{array}$ & 17 & 17.5 & $\begin{array}{l}+0.5 \\
\end{array}$ & 17.4 & $\begin{array}{l}+0.4 \\
\end{array}$ \\
\hline-18 & \begin{tabular}{|l|}
-13.3 \\
\end{tabular} & +4.7 & -14.1 & $\begin{array}{l}+3.9 \\
\end{array}$ & 18 & 18.3 & +0.3 & 18.3 & +0.3 \\
\hline-17 & -12.4 & +4.6 & \begin{tabular}{|l}
-13.2 \\
\end{tabular} & $\begin{array}{r}+3.8 \\
\end{array}$ & 19 & 19.2 & $\begin{array}{r}+0.2 \\
\end{array}$ & 19.3 & $\begin{array}{r}+0.3 \\
\end{array}$ \\
\hline-16 & -11.5 & +4.5 & -12.3 & $\begin{array}{r}+3.7 \\
\end{array}$ & 20 & 20.1 & $\begin{array}{l}+0.1 \\
\end{array}$ & 20.2 & $\begin{array}{l}+0.2 \\
\end{array}$ \\
\hline-15 & -10.6 & +4.4 & -11.4 & $\begin{array}{l}+3.6 \\
\end{array}$ & 21 & 21.0 & 0.0 & 21.1 & +0.1 \\
\hline-14 & -9.8 & +4.2 & -10.5 & $\begin{array}{r}+3.5 \\
\end{array}$ & 22 & 21.8 & -0.2 & 22.0 & 0.0 \\
\hline-13 & -8.9 & +4.1 & -9.6 & $\begin{array}{r}+3.4 \\
\end{array}$ & 23 & 22.7 & $\begin{array}{l}-0.3 \\
\end{array}$ & 22.9 & -0.1 \\
\hline-12 & -8.0 & +4.0 & -8.7 & $\begin{array}{r}+3.3 \\
\end{array}$ & 24 & 23.6 & -0.4 & 23.8 & -0.2 \\
\hline-11 & -7.1 & +3.9 & -7.8 & +3.2 & 25 & 24.5 & -0.5 & 24.7 & -0.3 \\
\hline-10 & -6.2 & +3.8 & -6.9 & $\begin{array}{r}+3.1 \\
\end{array}$ & 26 & 25.4 & -0.6 & 25.6 & -0.4 \\
\hline-9 & $\begin{array}{l}-5.4 \\
\end{array}$ & +3.6 & -6.0 & $\begin{array}{l}+3.0 \\
\end{array}$ & 27 & 26.2 & $\begin{array}{l}-0.8 \\
\end{array}$ & 26.5 & -0.5 \\
\hline-8 & -4.5 & +3.5 & -5.1 & +2.9 & 28 & 27.1 & $\begin{array}{l}-0.9 \\
\end{array}$ & 27.4 & -0.6 \\
\hline-7 & -3.6 & +3.4 & -4.2 & +2.8 & 29 & 28.0 & -1.0 & 28.3 & -0.7 \\
\hline-6 & -2.7 & +3.3 & \begin{tabular}{|l|}
-3.3 \\
\end{tabular} & $\begin{array}{r}+2.7 \\
\end{array}$ & 30 & 28.9 & -1.1 & 29.2 & -0.8 \\
\hline-5 & -1.9 & +3.1 & \begin{tabular}{|l|}
-2.4 \\
\end{tabular} & -2.6 & 31 & 29.8 & -1.2 & 30.1 & $\begin{array}{l}-0.9 \\
\end{array}$ \\
\hline-4 & -1.0 & +3.0 & -1.5 & $\begin{array}{r}+2.5 \\
\end{array}$ & 32 & 30.6 & -1.4 & 31.0 & -1.0 \\
\hline-3 & -0.1 & +2.9 & -0.6 & +2.4 & 33 & 31.5 & -1.5 & 31.9 & -1.1 \\
\hline-2 & 0.8 & +2.8 & 0.3 & $\begin{array}{r}+2.3 \\
\end{array}$ & 34 & 32.4 & $\begin{array}{l}-1.6 \\
\end{array}$ & 32.8 & -1.2 \\
\hline-1 & 1.7 & +2.7 & 1.2 & +2.2 & 35 & 33.3 & -1.7 & 33.7 & -1.3 \\
\hline 0 & 2.5 & +2.5 & 2.1 & +2.1 & 36 & 34.1 & -1.9 & 34.6 & -1.4 \\
\hline 1 & 3.4 & +2.4 & 3.0 & $\begin{array}{l}+2.0 \\
\end{array}$ & 37 & 35.0 & -2.0 & 35.5 & -1.5 \\
\hline 2 & 4.3 & +2.3 & 3.9 & $\begin{array}{l}+1.9 \\
\end{array}$ & 38 & 35.9 & -2.1 & 36.4 & -1.6 \\
\hline 3 & 5.2 & +2.2 & 4.8 & $\begin{array}{l}+1.8 \\
\end{array}$ & 39 & 36.8 & -2.2 & 37.3 & -1.7 \\
\hline 4 & 6.0 & $\begin{array}{l}+2.0 \\
\end{array}$ & 5.7 & $\begin{array}{l}+1.7 \\
\end{array}$ & 40 & 37.7 & -2.3 & 38.2 & -1.8 \\
\hline
\end{tabular}


Mylostyvyi Roman, Chernenko Oleksandr, Lisna Alisa

End of the Table 1

\begin{tabular}{|c|c|c|c|c|c|c|c|c|c|}
\hline \multirow[t]{2}{*}{$\mathbf{T}$} & \multicolumn{2}{|c|}{$\begin{array}{c}\text { Cowshed } \\
\text { carcass type, } \\
\text { n=334 }\end{array}$} & \multicolumn{2}{|c|}{$\begin{array}{c}\text { Cowshed } \\
\text { hangar type, } \\
n=493\end{array}$} & \multirow[t]{2}{*}{$\mathbf{T}$} & \multicolumn{2}{|c|}{$\begin{array}{c}\text { Cowshed } \\
\text { carcass type, } \\
n=334\end{array}$} & \multicolumn{2}{|c|}{$\begin{array}{c}\text { Cowshed hangar } \\
\text { type, } n=493\end{array}$} \\
\hline & $\mathbf{T}_{\mathrm{CCT}}$ & $\begin{array}{c}+/- \\
\text { toward T }\end{array}$ & $\mathbf{T}_{\mathrm{CHT}}$ & $\begin{array}{c}+/- \\
\text { toward T }\end{array}$ & & $\mathbf{T}_{\text {CCT }}$ & $\begin{array}{c}+/- \\
\text { toward T }\end{array}$ & $\mathbf{T}_{\mathrm{CHT}}$ & $\begin{array}{c}+/- \\
\text { toward T }\end{array}$ \\
\hline 6 & $\begin{array}{l}7.8 \\
\end{array}$ & +1.8 & 7.5 & +1.5 & 42 & 39.4 & -2.6 & 40.0 & -2.0 \\
\hline 7 & 8.7 & +1.7 & 8.4 & +1.4 & 43 & 40.3 & -2.7 & 40.9 & -2 \\
\hline 8 & 9.6 & +1.6 & 9.3 & +1.3 & 44 & 41.2 & -2.8 & 41.8 & -2.2 \\
\hline 9 & \begin{tabular}{|l|l}
10.4 \\
\end{tabular} & +1.4 & 10.2 & +1.2 & 45 & 42.0 & -3.0 & 42.7 & -2.3 \\
\hline 10 & 11.3 & +1.3 & 11.1 & +1.1 & 46 & 42.9 & -3.1 & 43.6 & -2.4 \\
\hline
\end{tabular}

Note. T - ambient air temperature $\left({ }^{\circ} \mathrm{C}\right)$; TCCT - air temperature in the cowshed carcass type $\left({ }^{\circ} \mathrm{C}\right)$; TCHT - air temperature in the cowshed hangar type $\left({ }^{\circ} \mathrm{C}\right)$.

Table 2

Calculated values of relative humidity in different types of cowsheds depending on the humidity of the outside air

\begin{tabular}{|c|c|c|c|c|c|c|c|c|c|}
\hline \multirow{2}{*}{ RH } & \multicolumn{2}{|c|}{$\begin{array}{c}\text { Cowshed } \\
\text { carcass type, } \\
\mathbf{n}=334\end{array}$} & \multicolumn{2}{|c|}{$\begin{array}{c}\text { Cowshed } \\
\text { hangar type, } \\
n=493\end{array}$} & \multirow{2}{*}{ RH } & \multicolumn{2}{|c|}{$\begin{array}{c}\text { Cowshed } \\
\text { carcass type, } \\
\mathbf{n}=\mathbf{3 3 4}\end{array}$} & \multicolumn{2}{|c|}{$\begin{array}{c}\text { Cowshed } \\
\text { hangar type, } \\
n=493\end{array}$} \\
\hline & $\mathbf{R H}_{\mathrm{CCT}}$ & $\begin{array}{c}+/- \\
\text { toward } \\
\text { RH }\end{array}$ & $\mathbf{R H}_{\text {CHT }}$ & $\begin{array}{c}+/- \\
\text { toward } \\
\text { RH }\end{array}$ & & $\mathbf{R H}_{\mathrm{CCT}}$ & $\begin{array}{c}+/- \\
\text { toward } \\
\text { RH }\end{array}$ & $\mathbf{R H}_{\text {CHT }}$ & $\begin{array}{c}+/- \\
\text { toward } \\
\text { RH }\end{array}$ \\
\hline 17 & 28.2 & +11.2 & 21.8 & +4.8 & 59 & 60.7 & $\begin{array}{l}+1.7 \\
\end{array}$ & 60.6 & $\begin{array}{l}+1.6 \\
\end{array}$ \\
\hline 18 & 29.0 & +11.0 & 22.7 & +4.7 & 60 & 61.5 & +1.5 & 61.5 & +1.5 \\
\hline 19 & 29.7 & +10.7 & 23.6 & +4.6 & 61 & 62.3 & +1.3 & 62.4 & +1.4 \\
\hline 20 & 30.5 & +10.5 & 24.6 & +4.6 & 62 & 63.0 & +1.0 & 63.3 & $\begin{array}{l}+1.3 \\
\end{array}$ \\
\hline 21 & 31.3 & +10.3 & 25.5 & +4.5 & 63 & 63.8 & $\begin{array}{l}+0.8 \\
\end{array}$ & 64.3 & +1.3 \\
\hline 22 & 32.1 & +10.1 & 26.4 & +4.4 & 64 & 64.6 & +0.6 & 65.2 & +1.2 \\
\hline 23 & 32.8 & +9.8 & 27.3 & +4.3 & 65 & 65.4 & +0.4 & 66.1 & +1.1 \\
\hline 24 & 33.6 & +9.6 & 28.3 & +4.3 & 66 & 66.1 & +0.1 & 67.0 & $\begin{array}{l}+1.0 \\
\end{array}$ \\
\hline 25 & 34.4 & $\begin{array}{l}+9.4 \\
\end{array}$ & 29.2 & +4.2 & 67 & 66.9 & -0.1 & 67.9 & $\begin{array}{l}+0.9 \\
\end{array}$ \\
\hline 26 & 35.2 & +9.2 & 30.1 & +4.1 & 68 & 67.7 & -0.3 & 68.9 & +0.9 \\
\hline 27 & 35.9 & $\begin{array}{l}+8.9 \\
\end{array}$ & 31.0 & +4.0 & 69 & 68.4 & -0.6 & 69.8 & $\begin{array}{l}+0.8 \\
\end{array}$ \\
\hline 28 & 36.7 & $\begin{array}{l}+8.7 \\
\end{array}$ & 32.0 & +4.0 & 70 & 69.2 & -0.8 & 70.7 & $\begin{array}{l}+0.7 \\
\end{array}$ \\
\hline 29 & 37.5 & +8.5 & 32.9 & +3.9 & 71 & 70.0 & -1.0 & 71.6 & +0.6 \\
\hline 30 & 38.3 & +8.3 & 33.8 & +3.8 & 72 & 70.8 & -1.2 & 72.6 & +0.6 \\
\hline 31 & 39.0 & +8.0 & 34.7 & +3.7 & 73 & 71.5 & -1.5 & 73.5 & +0.5 \\
\hline 32 & 39.8 & +7.8 & 35.6 & +3.6 & 74 & 72.3 & -1.7 & 74.4 & +0.4 \\
\hline 33 & 40.6 & +7.6 & 36.6 & +3.6 & 75 & 73.1 & -1.9 & 75.3 & +0.3 \\
\hline
\end{tabular}


Chapter «Veterinary communications»

End of the Table 2

\begin{tabular}{|c|c|c|c|c|c|c|c|c|c|}
\hline \multirow{2}{*}{ RH } & \multicolumn{2}{|c|}{$\begin{array}{c}\text { Cowshed } \\
\text { carcass type, } \\
\mathbf{n}=\mathbf{3 3 4}\end{array}$} & \multicolumn{2}{|c|}{$\begin{array}{c}\text { Cowshed } \\
\text { hangar type, } \\
n=493\end{array}$} & \multirow{2}{*}{ RH } & \multicolumn{2}{|c|}{$\begin{array}{c}\text { Cowshed } \\
\text { carcass type, } \\
n=334\end{array}$} & \multicolumn{2}{|c|}{$\begin{array}{c}\text { Cowshed } \\
\text { hangar type, } \\
\text { n=493 }\end{array}$} \\
\hline & $\mathbf{R H}_{\mathrm{CCT}}$ & $\begin{array}{c}+/- \\
\text { toward } \\
\text { RH }\end{array}$ & $\mathbf{R H}_{\text {CHT }}$ & $\begin{array}{c}+/- \\
\text { toward } \\
\text { RH }\end{array}$ & & $\mathbf{R H}_{\mathrm{CCT}}$ & $\begin{array}{c}+/- \\
\text { toward } \\
\text { RH }\end{array}$ & $\mathbf{R H}_{\text {CHT }}$ & $\begin{array}{c}+/- \\
\text { toward } \\
\text { RH }\end{array}$ \\
\hline 35 & 42.1 & +7.1 & 38.4 & +3.4 & 77 & 74.6 & -2.4 & 77.2 & +0.2 \\
\hline 36 & 42.9 & +6.9 & \begin{tabular}{|l}
39.3 \\
\end{tabular} & +3.3 & 78 & 75.4 & -2.6 & 78.1 & +0.1 \\
\hline 37 & 43.7 & +6.7 & 40.3 & +3.3 & 79 & 76.2 & -2.8 & 79.0 & 0.0 \\
\hline 38 & 44.5 & +6.5 & 41.2 & +3.2 & 80 & 77.0 & -3.0 & 79.9 & -0.1 \\
\hline 39 & 45.2 & +6.2 & 42.1 & +3.1 & 81 & 77.7 & \begin{tabular}{|l|}
-3.3 \\
\end{tabular} & 80.9 & -0.1 \\
\hline 40 & 46.0 & +6.0 & 43.0 & +3.0 & 82 & 78.5 & -3.5 & 81.8 & -0.2 \\
\hline 41 & 46.8 & +5.8 & $\begin{array}{l}43.9 \\
\end{array}$ & +2.9 & 83 & 79.3 & -3.7 & 82.7 & \begin{tabular}{|c|}
-0.3 \\
\end{tabular} \\
\hline 42 & 47.5 & +5.5 & 44.9 & +2.9 & 84 & 80.1 & -3.9 & 83.6 & -0.4 \\
\hline 43 & 48.3 & +5.3 & 45.8 & +2.8 & 85 & 80.8 & -4.2 & 84.6 & -0.4 \\
\hline 44 & 49.1 & +5.1 & 46.7 & +2.7 & 86 & 81.6 & -4.4 & 85.5 & -0.5 \\
\hline 45 & 49.9 & +4.9 & 47.6 & +2.6 & 87 & 82.4 & -4.6 & 86.4 & -0.6 \\
\hline 46 & 50.6 & +4.6 & 48.6 & +2.6 & 88 & 83.2 & -4.8 & 87.3 & -0.7 \\
\hline 47 & 51.4 & +4.4 & 49.5 & +2.5 & 89 & 83.9 & $\begin{array}{l}-5.1 \\
\end{array}$ & 88.3 & $\begin{array}{l}-0.7 \\
\end{array}$ \\
\hline 48 & 52.2 & +4.2 & $\begin{array}{l}50.4 \\
\end{array}$ & +2.4 & 90 & 84.7 & \begin{tabular}{|l|}
-5.3 \\
\end{tabular} & 89.2 & -0.8 \\
\hline 49 & 53.0 & +4.0 & 51.3 & +2.3 & 91 & 85.5 & -5.5 & 90.1 & -0.9 \\
\hline 50 & 53.7 & +3.7 & 52.3 & +2.3 & 92 & 86.3 & -5.7 & 91.0 & -1.0 \\
\hline 51 & 54.5 & +3.5 & 53.2 & +2.2 & 93 & 87.0 & -6.0 & 91.9 & -1.1 \\
\hline 52 & 55.3 & +3.3 & 54.1 & +2.1 & \begin{tabular}{|l|}
94 \\
\end{tabular} & 87.8 & -6.2 & 92.9 & -1.1 \\
\hline 53 & 56.1 & +3.1 & 55.0 & +2.0 & 95 & 88.6 & -6.4 & 93.8 & -1.2 \\
\hline 54 & 56.8 & +2.8 & 55.9 & $\begin{array}{l}+1.9 \\
\end{array}$ & 96 & 89.4 & -6.6 & 94.7 & -1.3 \\
\hline 55 & $\begin{array}{l}57.6 \\
\end{array}$ & +2.6 & $\begin{array}{l}56.9 \\
\end{array}$ & +1.9 & \begin{tabular}{|l|l}
97 \\
\end{tabular} & 90.1 & -6.9 & 95.6 & -1.4 \\
\hline 56 & 58.4 & +2.4 & 57.8 & +1.8 & 98 & 90.9 & -7.1 & 96.6 & -1.4 \\
\hline 57 & 59.2 & +2.2 & 58.7 & +1.7 & \begin{tabular}{|l|}
99 \\
\end{tabular} & 91.7 & $\begin{array}{l}-7.3 \\
\end{array}$ & 97.5 & -1.5 \\
\hline 58 & 59.9 & +1.9 & 59.6 & +1.6 & 100 & 92.4 & -7.6 & 98.4 & -1.6 \\
\hline
\end{tabular}

Note. RH - ambient air relative humidity (\%); RHCCT - air relative humidity in the cowshed carcass type (\%); RHCHT - air relative humidity in the cowshed hangar type (\%).

be from 6.0 to $11.2 \%$, and CHT from 1.6 to $4.8 \%$. With an increase in the relative humidity of the environment to $66.0-78.0 \%$, this indicator in the rooms will be higher than outside. Above these values and up to the maximum $(100 \%)$ saturation of external air with water vapor, the relative humidity in the cowsheds will remain below external indicators. 

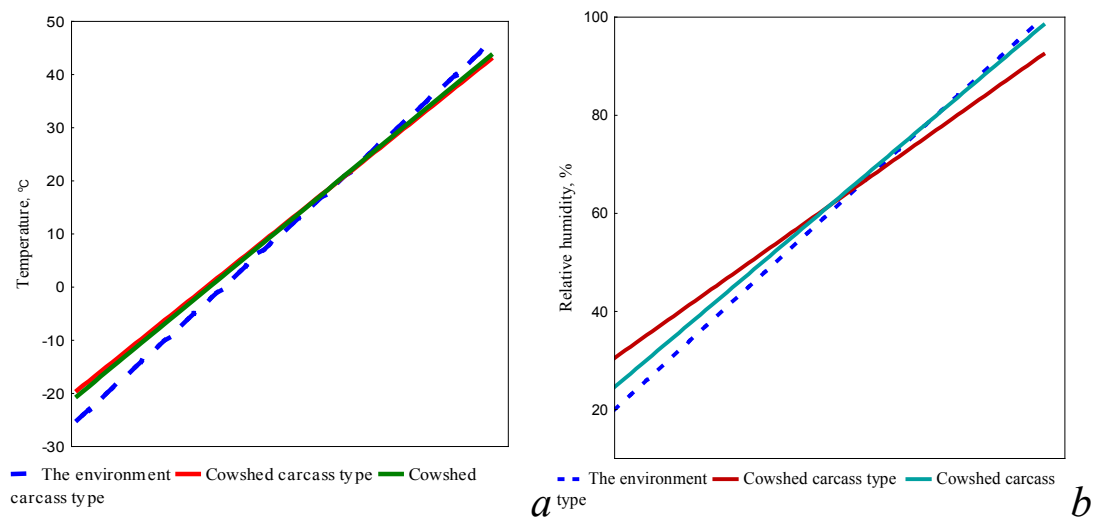

Figure 2. The dependence of temperature (a) and humidity (b) in different types of rooms on the state of the environment

Therefore, the temperature and humidity conditions in the rooms of uninsulated type depend on the external environment and depend on the design features of the rooms, which can affect the state of comfort of animals.

\section{Assessment of the state of comfort of dairy cows using a temperature-humidity index}

Temperature and humidity conditions in uninsulated cowsheds are close to environmental conditions. The difference between external and internal temperature in such rooms is insignificant. According to scientists $[21$, p. $41 ; 32$, p. $37 ; 35$, p. 225$]$, during the transitional and hot period of the year, it is up to $5^{\circ} \mathrm{C}$. In the cold period of the year, water and manure can freeze in an uninsulated cowshed, incapacitate machinery and equipment fail [13, p. 25]. Our research and direct presence in the premises (in cold and heat), confirm the data obtained by the authors.

A more serious problem is high air temperatures, to which dairy cows are very sensitive $[7$, p. $260 ; 11$, p. 37]. The heat causes a change in the clinical state of animals [4, p. 4939], impaired metabolic homeostasis [8, p. 1244], a decrease in milk yield in cows $[15$, p. $319 ; 27$, p. 2017; 30 , p. 40; 31, p. 97]. 


\section{Chapter «Veterinary communications»}

The temperature-humidity index (THI) is used to assess the effect of heat on dairy cattle [34, p. 165]. The methods for calculating it are very diverse [3, p. 1947], as is the degree of heat stress that he characterizes [10]. However, among researchers the calculation of THI is not widely used. This is not available in our literature. It was used to assess the effect of heat on dairy cows only in recent studies $[29$, p. 128]. They indicate a reliable relationship between the temperature and humidity of the air and the milk yield of animals at the barn location. Therefore, the method of calculating the THI [14, p. 862], was used in our research.

Since cattle tolerate lower temperatures more easily than heat, it is important to simultaneously control the high temperatures and relative humidity of the air, which, as is well known, jointly affect the thermoregulation of animals. The state of comfort of the cows was determined by calculating the temperature-humidity index (THI) by the equation

$$
T H I=1.8 \times T-(1-R H / 100) \times(T-14.3)+32
$$

where $T H I$ - temperature-humidity index

$T$ - air temperature, ${ }^{\circ} \mathrm{C}$

$R H$ - relative humidity, \%

Based on the archive records $(n=1924)$ of air temperature and humidity, a temperature-humidity index was calculated (Table 3 ), the value of which with a high degree of probability (Fig. 3) can be predicted based on the externals ambient temperatures using the equation

$$
T H I_{E N}=46.97807+0.96075 \times T
$$

where $T H I_{E N}$ - temperature-humidity index of the environment

$T$ - ambient air temperature, ${ }^{\circ} \mathrm{C}$.

Considering the difference between the state of the environment and the climate of the premises, the probable values of the temperature-humidity index in the cowshed carcass type (7) and cowshed hangar type (8) were calculated

$$
\begin{aligned}
T H I_{C C T} & =47.05419+0.99649 \times T \\
T H I_{C H T} & =46.00549+1.04460 \times T
\end{aligned}
$$

where $T H I_{C C T}$ temperature-humidity index in the cowshed carcass type

$\mathrm{THI}_{\mathrm{CHT}}$ - temperature-humidity index in the cowshed hangar type

$T$ - ambient air temperature, ${ }^{\circ} \mathrm{C}$.

The calculated data (Table 3) indicate a slight difference in the indices of the temperature-humidity index in the uninsulated cowsheds of different 


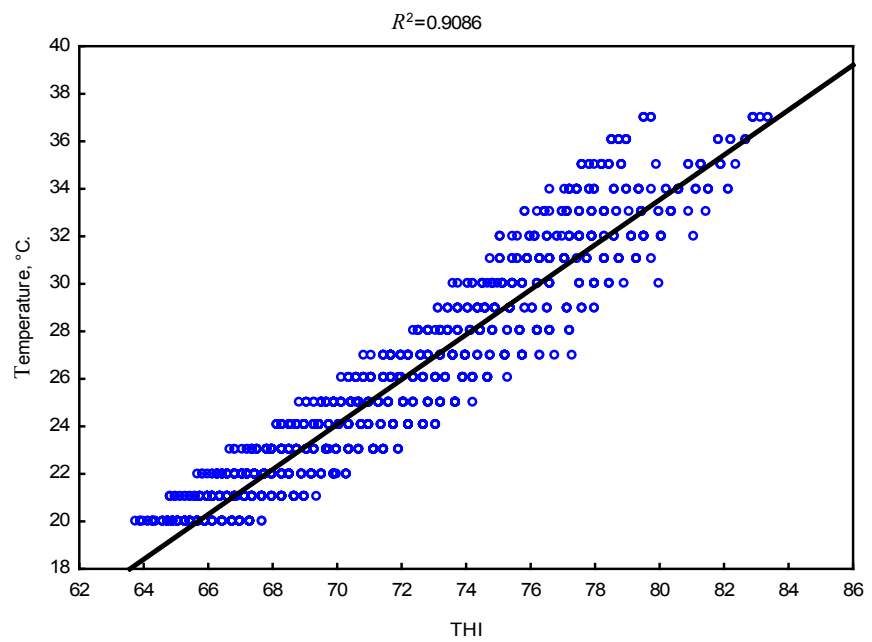

Figure 3. Dependence of temperature-humidity index on ambient air temperature

Table 3

The calculated values of temperature-humidity index, depending on the ambient temperature and the type of room

\begin{tabular}{|c|c|c|c|c|c|c|c|}
\hline $\mathbf{T}$ & $\mathbf{T H I}_{\mathbf{E N}}$ & $\mathbf{T H I}_{\mathbf{C C T}}$ & $\mathbf{T H I}_{\mathbf{C H T}}$ & $\mathbf{T}$ & $\mathbf{T H I}_{\mathbf{E N}}$ & $\mathbf{T H I}_{\mathbf{C C T}}$ & $\mathbf{T H I}_{\mathbf{C H T}}$ \\
\hline 20 & 66.2 & 67.0 & 66.9 & 33 & 78.7 & 79.9 & 80.5 \\
\hline 21 & 67.2 & 68.0 & 67.9 & 34 & 79.6 & 80.9 & 81.5 \\
\hline 22 & 68.1 & 69.0 & 69.0 & 35 & 80.6 & 81.9 & 82.6 \\
\hline 23 & 69.1 & 70.0 & 70.0 & 36 & 81.6 & 82.9 & 83.6 \\
\hline 24 & 70.0 & 71.0 & 71.1 & 37 & 82.5 & 83.9 & 84.7 \\
\hline 25 & 71.0 & 72.0 & 72.1 & 38 & 83.5 & 84.9 & 85.7 \\
\hline 26 & 72.0 & 73.0 & 73.2 & 39 & 84.4 & 85.9 & 86.7 \\
\hline 27 & 72.9 & 74.0 & 74.2 & 40 & 85.4 & 86.9 & 87.8 \\
\hline 28 & 73.9 & 75.0 & 75.3 & 41 & 86.4 & 87.9 & 88.8 \\
\hline 29 & 74.8 & 76.0 & 76.3 & 42 & 87.3 & 88.9 & 89.9 \\
\hline 30 & 75.8 & 76.9 & 77.3 & 43 & 88.3 & 89.9 & 90.9 \\
\hline 31 & 76.8 & 77.9 & 78.4 & 44 & 89.3 & 90.9 & 92.0 \\
\hline 32 & 77.7 & 78.9 & 79.4 & 45 & 90.2 & 91.9 & 93.0 \\
\hline
\end{tabular}




\section{Chapter «Veterinary communications»}

types (0.1-1.1 units). However, the difference between the THI outside and inside the barns of lightweight construction of 2-3 units, must provide for the adoption of appropriate technical solutions to create comfortable conditions for dairy cattle.

Researchers at Lallemand Animal Nutrition [17, p. 26] also give an equation (5) in their materials. The value of THI below 68 corresponds to comfortable conditions for animals and is the limit above which they are subject to thermal stress. Thus, the value of THI at the level of 68-71 corresponds to a slight stress, within 72-79 to moderate stress, whereas at 80-89, the cows are in a state of strong, and 90-99 - very strong (hard) stress [23, p. 18].

Other Russian authors [5, p. 5], when estimating the degree of manifestation of heat stress, used the following THI calculation (equation 9)

$$
T H I=0.72(W+D)+40.6
$$

where $W$ and $D$ are, respectively, the temperature $\left({ }^{\circ} \mathrm{C}\right)$ of a wet and dry thermometer.

Researchers believe that the index value below 68 indicates that the cow is in the comfort zone, if it ranges from 69 to 72 , then this corresponds to the onset of heat stress; a value from 73 to 78 characterizes the development of heat stress. If the indicator is in the range from 79 to 84 , then the animal is subject to severe heat stress, and if it is greater than 85 , death is possible. However, the simultaneous measurement of the temperature of dry and wet thermometers is not always possible. Therefore, the use of this equation is not very convenient.

The choice of the necessary equation for the calculation of THI depends on the climatic conditions. In a humid climate, it is necessary to use an index with a high specific weight for humidity, whereas higher temperature weights are best for determining heat stress in arid climate [3, p. 1947].

Convenient in assessing the comfort of animals is to use the table of values of THI in terms of temperature and relative humidity. It will look like this (Table 4) taking into account regional climatic features of the location of the dairy complex (Steppe of Ukraine). A similar table is also given by other authors, referring to the scale of temperature stress assessment at the University of Arizona [5, p. 5; 18, p. 32; 19, p. 34].

Between temperature and humidity of the environment in the range from +20 to $+37^{\circ} \mathrm{C}(\mathrm{n}=1924)$ a tight bond was found $(\mathrm{r}=-0.60 ; \mathrm{P}<0.01)$. 
Mylostyvyi Roman, Chernenko Oleksandr, Lisna Alisa

Table 4

Calculated THI values taking into account the regional climatic conditions of the steppe of Ukraine

\begin{tabular}{|c|c|c|c|c|c|c|c|c|c|c|c|c|c|c|c|c|c|}
\hline \multirow{2}{*}{$\begin{array}{c}\text { Temperature, } \\
{ }^{\circ} \mathrm{C}\end{array}$} & \multicolumn{17}{|c|}{ Relative humidity,\% } \\
\hline & 15 & 20 & 25 & 30 & 35 & 40 & 45 & 50 & 55 & 60 & 65 & 70 & 75 & 80 & 85 & 90 & 95 \\
\hline 20 & 63 & 63 & 64 & 64 & 64 & 65 & 65 & 65 & 65 & 66 & 66 & 66 & 67 & 67 & 67 & 67 & 68 \\
\hline 21 & 64 & 64 & 65 & 65 & 65 & 66 & 66 & 66 & 67 & 67 & 67 & 68 & 68 & 68 & 69 & 69 & 69 \\
\hline 22 & 65 & 65 & 66 & 66 & 67 & 67 & 67 & 68 & 68 & 69 & 69 & 69 & 70 & 70 & 70 & 71 & 71 \\
\hline 23 & 66 & 66 & 67 & 67 & 68 & 68 & 69 & 69 & 69 & 70 & 70 & 71 & 71 & 72 & 72 & 73 & 73 \\
\hline 24 & 67 & 67 & 68 & 68 & 69 & 69 & 70 & 70 & 71 & 71 & 72 & 72 & 73 & 73 & 74 & 74 & 75 \\
\hline 25 & 68 & 68 & 69 & 70 & 70 & 71 & 71 & 72 & 72 & 73 & 73 & 74 & 74 & 75 & 75 & 76 & 76 \\
\hline 26 & 69 & 69 & 70 & 71 & 71 & 72 & 72 & 73 & 74 & 74 & 75 & 75 & 76 & 76 & 77 & 78 & 78 \\
\hline 27 & 70 & 70 & 71 & 72 & 72 & 73 & 74 & 74 & 75 & 76 & 76 & 77 & 77 & 78 & 79 & 79 & 80 \\
\hline 28 & 71 & 71 & 72 & 73 & 73 & 74 & 5 & 76 & 76 & 77 & 78 & 78 & 79 & 80 & 80 & 81 & 82 \\
\hline 29 & 72 & 72 & 73 & 74 & 75 & 75 & 76 & 77 & 78 & 78 & 79 & 80 & 81 & 81 & 82 & 83 & 83 \\
\hline 30 & 73 & 73 & 74 & 75 & 76 & 77 & 77 & 78 & 79 & 80 & 81 & 81 & 82 & 83 & 84 & 84 & 85 \\
\hline 31 & 74 & 74 & 75 & 76 & 77 & 78 & 79 & 79 & 80 & 81 & 82 & 83 & 84 & 84 & 85 & 86 & 87 \\
\hline 32 & 75 & 75 & 76 & 77 & 78 & 79 & 80 & 81 & 82 & 83 & 83 & 84 & 85 & 86 & 87 & 88 & 89 \\
\hline 33 & 76 & 76 & 77 & 78 & 79 & 80 & 81 & 82 & 83 & 84 & 85 & 86 & 87 & 88 & 89 & 90 & 90 \\
\hline 34 & 76 & 77 & 78 & 79 & 80 & 81 & 82 & 83 & 84 & 85 & 86 & 87 & 88 & 89 & 90 & 91 & 92 \\
\hline 35 & 77 & 78 & 79 & 81 & 82 & 83 & 84 & 85 & 86 & 87 & 88 & 89 & 90 & 91 & 92 & 93 & 94 \\
\hline 36 & 78 & 79 & 81 & 82 & 83 & 84 & 85 & 86 & 87 & 88 & 89 & 90 & 91 & 92 & 94 & 95 & 96 \\
\hline 37 & 79 & 80 & 82 & 83 & 84 & 85 & 86 & 87 & 88 & 90 & 91 & 92 & 93 & 94 & 95 & 96 & 97 \\
\hline 38 & 80 & 81 & 83 & 84 & 85 & 86 & 87 & 89 & 90 & 91 & 92 & 93 & 94 & 96 & 97 & 98 & 99 \\
\hline 39 & 81 & 82 & 84 & 85 & 86 & 87 & 89 & 90 & 91 & 92 & 94 & 95 & 96 & 97 & 98 & 100 & 101 \\
\hline 40 & 82 & 83 & 85 & 86 & 87 & 89 & 90 & 91 & 92 & 94 & 95 & 96 & 08 & 99 & 100 & 101 & 103 \\
\hline
\end{tabular}

Note. Green - comfort zone; yellow - a little stress; orange - moderate stress; brown strong stress; violet - very strong (hard) stress.

By the method of simple linear regression, it is established that when the temperature rises by one degree Celsius, the relative humidity of the air will decrease by approximately two percent $\left(\mathrm{R}^{2}=0.36\right)$. At the same time, the range of fluctuations in relative humidity of the air at the same temperature values was quite large (Figure 4) and depended on changeable weather conditions.

According to the data (Table 4), animals can be exposed to low heat stress even at a temperature of $20^{\circ} \mathrm{C}$, moderately at $23^{\circ} \mathrm{C}$, and are in a state of severe heat stress at $30^{\circ} \mathrm{C}$ (including taking account the type of uninsulated cowsheds). The likelihood of severe stress in dairy cows is extremely low, but it is theoretically possible at air temperatures above $32^{\circ} \mathrm{C}$.

Thus, the calculated values of temperatures and relative humidity in the rooms, obtained by constructing linear regression models, make it possible to predict the values of THI in uninsulated cowsheds. They can be used 


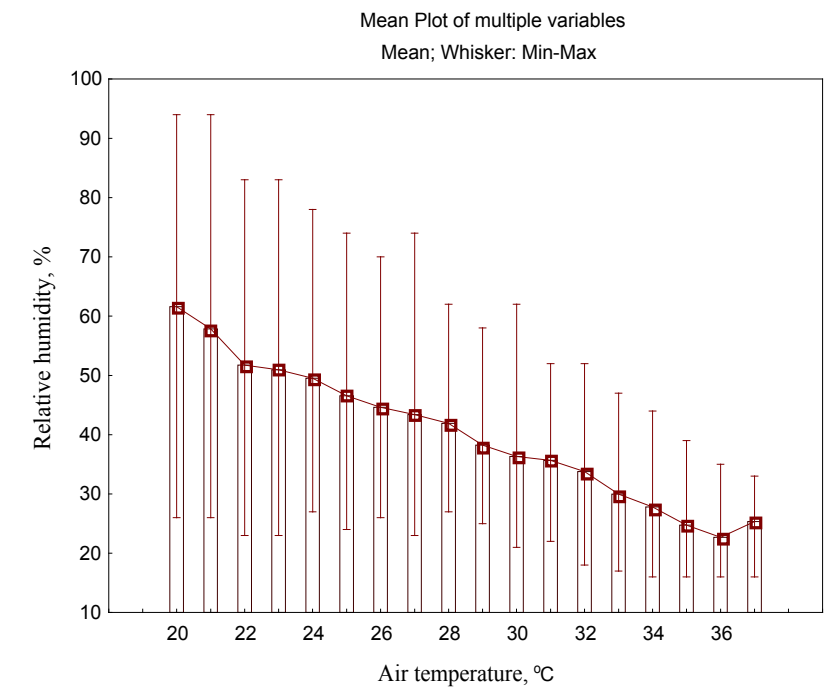

目 Mean

I Min-Max

\section{Figure 4. Dynamics of temperature and humidity} of the air at the location of the dairy complex in the hot season

as a reference when choosing the type of room for keeping dairy cows and assessing the state of their comfort, given the climatic features of the temperate continental climate of the Steppe of Ukraine.

\section{Conclusion}

Repeated measurement of temperature and humidity of air inside and outside the premises for animals allows predicting the state of the microclimate by building mathematical models. It has been established that the temperature and humidity conditions in an uninsulated cowsheds are directly determined by the state of the environment, and also depend on the design features of the room. The temperature-humidity index is a convenient integral indicator of the climate in the cowsheds. It allows you to evaluate the comfort of dairy cows in conditions of high temperatures. The THI prediction for an individual dairy complex, taking into account its geographical and climatic location, will make timely management decisions to normalize the climate in an uninsulated cowshed. 


\section{References:}

1. Anderson, N.G. (1997). Cold housing and open housing - effects on health, management and production dairy cattle. Proceedings of the 9th International Congress in Animal Hygiene, 17-21 August 1997, Helsinki, Finland. Pp. 481-487.

2. Angrecka, S. \& Herbut, P. (2016). Conditions for cold stress development in dairy cattle kept in free stall barn during severe frosts. Czech Journal of Animal Science, 60 (No. 2), 81-87. doi: 10.17221/7978-cjas

3. Bohmanova, J., Misztal, I. \& Cole, J. B. (2007). Temperature-Humidity Indices as Indicators of Milk Production Losses due to Heat Stress. Journal of Dairy Science, 90(4), 1947-1956. doi: 10.3168/jds.2006-513.

4. Bravo, D. M. \& Wall, E. H. (2016). The rumen and beyond: Nutritional physiology of the modern dairy cow 1. Journal of Dairy Science, 99(6), 4939-4940. doi: 10.3168/jds.2015-10191.

5. Buryakov N. P., Buryakova M. A., Aleshin D. E. (2016). Teplovoy stress i osobennosti kormleniya molochnogo skota [Heat Stress and Heat Stress and Feeding Features of the Dairy Cattle]. Rossiyskiy veterinarnyiy jurnal, 3, 5-13. (in Russian)

6. Carabaño, M. J., Logar, B., Bormann, J., Minet, J., Vanrobays, M.-L., Díaz, C., . . . Hammami, H. (2016). Modeling heat stress under different environmental conditions. Journal of Dairy Science, 99(5), 3798-3814. doi: 10.3168/jds.2015-10212/

7. Das, R., Sailo, L., Verma, N., Bharti, P., Saikia, J., Imtiwati \& Kumar, R. (2016). Impact of heat stress on health and performance of dairy animals: A review. Veterinary World, 9(3), 260-268. doi: 10.14202/vetworld.2016.260-268

8. Fan, C., Su, D., Tian, H., Li, X., Li, Y., Ran, L., ... Cheng, J. (2018). Liver metabolic perturbations of heat-stressed lactating dairy cows. Asian-Australasian Journal of Animal Sciences, 31(8), 1244-1251. doi: 10.5713/ajas.17.0576

9. Fiedler, M., Hoffmann, G., von Bobrutzki, K., Matzarakis, A. (2010). Biometeorological investigations in dairy cowsheds. In: Matzarakis, A., Mayer, F. \& Chmielewski, M. (Eds.) Proceedings of the 7th Conference in Biometeorology. BIOMET 12 -14 April 2010, Freiburg, Germany.

10. Fodor, N., Foskolos, A., Topp, C. F. E., Moorby, J. M., Pásztor, L. \& Foyer, C. H. (2018). Spatially explicit estimation of heat stress-related impacts of climate change on the milk production of dairy cows in the United Kingdom. PLOS ONE, 13(5), e0197076. doi: 10.1371/journal.pone.0197076

11. Fournel, S., Ouellet, V., \& Charbonneau, É. (2017). Practices for Alleviating Heat Stress of Dairy Cows in Humid Continental Climates: A Literature Review. Animals, 7(12), 37. doi: 10.3390/ani7050037.

12. Gantner, V., Bobic, T., Gantner, R., Gregic, M., Kuterovac, K., Novakovic, J. \& Potocnik, K. (2017). Differences in response to heat stress due to production level and breed of dairy cows. International Journal of Biometeorology, 61(9), 1675-1685. doi: 10.1007/s00484-017-1348-7

13. Hodanovich B. (2012). «Holodnyie» korovniki: uroki surovoy zimyi i jarkogo leta [«Cold» cowsheds: lessons from the harsh winter and hot summer]. Jivotnovodstvo Rossii. Spetsvyipusk, 25-28. (in Russian)

14. Kibler, H.H. (1964). Environmental physiology and shelter engineering. LXVII. Thermal effects of various temperature-humidity combinations on Holstein 


\section{Chapter «Veterinary communications»}

cattle as measured by eight physiological responses. Res. Bull. Missouri Agric. Exp. Station. 862.

15. Lambertz, C., Sanker, C. \& Gauly, M. (2014). Climatic effects on milk production traits and somatic cell score in lactating Holstein-Friesian cows in different housing systems. Journal of Dairy Science, 97(1), 319-329. doi: $10.3168 /$ jds.2013-7217/

16. Liu, Z., Ezernieks, V., Wang, J., Arachchillage, N. W., Garner, J. B., Wales, W. J., ... Rochfort, S. (2017). Heat Stress in Dairy Cattle Alters Lipid Composition of Milk. Scientific Reports, 7(1). doi: 10.1038/s41598-017-01120-9

17. Malinin I. (2017). Teplovoy stress: novyie faktyi [Heat stress: new evidence]. Jivotnovodstvo Rossii, 6, 26-28. (in Russian)

18. Malinin, I. \& Sadovnikova, N. (2016). Teplovoy stress: pravila igryi [Heat stress: rules of the game]. Jivotnovodstvo Rossii, S3, 32-35. (in Russian)

19. Malinin, I. \& Sadovnikova, N. (2016). Vliyanie teplovogo stressa na produktivnost molochnogo i myasnogo skota [Effect of heat stress on the productivity of dairy and beef cattle]. Effektivnoe jivotnovodstvo, 5(126), 34-37. (in Russian)

20. McDonald J. H. 2009. Handbook of Biological Statistics. Sparky House Publishing, Baltimore.

21. Molodkovets, O., Zakharenko, M. (2016). Microclimate livestock buildings and premises for loose-boxed maintenance, forsed and voluntary milking cows. Scientific Messenger LNUVMBT named after S.Z. Gzhytskyj, 18, 4(72), 41-46. (in Ukrainian)

22. Overton, M. W., Sischo, W. M., Temple, G. D. \& Moore, D. A. (2002). Using TimeLapse Video Photography to Assess Dairy Cattle Lying Behavior in a Free-Stall Barn. Journal of Dairy Science, 85(9), 2407-2413. doi: 10.3168/jds.s0022-0302(02)74323-3

23. Piron O. \& Malinin I. (2015). Nujno li predotvraschat teplovoy stress u doynyih korov? [Is it necessary to prevent heat stress in dairy cows?]. Effektivnoe jivotnovodstvo, 3-4(113), 18-20. (in Russian)

24. Schüller, L. K. \& Heuwieser, W. (2016). Measurement of heat stress conditions at cow level and comparison to climate conditions at stationary locations inside a dairy barn. Journal of Dairy Research, 83(03), 305-311. doi: $10.1017 / \mathrm{s} 0022029916000388$

25. Sejian, V., Pragna, P., Archana, P. R., Aleena, J., Krishnan, G., Bagath, M., Manimaran, A., Beena, V., Kurien, E. K., Varma, G. \& Bhatta, R. (2017). Heat Stress and Dairy Cow: Impact on Both Milk Yield and Composition. International Journal of Dairy Science, 12(1), 1-11. doi: 10.3923/ijds.2017.1.11

26. Skibiel, A. L., Zachut, M., do Amaral, B. C., Levin, Y. \& Dahl, G. E. (2018). Liver proteomic analysis of postpartum Holstein cows exposed to heat stress or cooling conditions during the dry period. Journal of Dairy Science, 101(1), 705-716. doi: 10.3168/jds.2017-13258

27. Tao, S., Orellana, R. M., Weng, X., Marins, T. N., Dahl, G. E. \& Bernard, J. K. (2018). Symposium review: The influences of heat stress on bovine mammary gland function. Journal of Dairy Science. doi: 10.3168/jds.2017-13727

28. Vaculíková, M., Komzáková, I. \& Chládek, G. (2017). The Effect of Low Air Temperature on Behaviour and Milk Production in Holstein Dairy Cows. 
Acta Universitatis Agriculturae et Silviculturae Mendelianae Brunensis, 65(5), 1623-1627. doi:10.11118/actaun201765051623

29. Vasilenko T., Milostiviy R., Kalinichenko A., Milostiva D. (2018). Heat stress in dairy cows in the central part of Ukraine and its economic consequences. Social and economic aspects of sustainable development of regions: monograph, $128-135$.

30. Vasilenko, T., Milostiviy, R. \& Kalinichenko, O. (2018). Influence of high temperature on dairy productivity of Ukrainian Schwyz. Relevant Issues of Development and Modernization of the Modern Science: The Experience of Countries of Eastern Europe and Prospects of Ukraine. doi: 10.30525/978-9934-571-26-8_3

31. Vasilenko, T. O., Milostiviy, R. V., Kalinichenko, O. O., Gutsulyak, G. S. \& Sazykina, E. M. (2018). Influence of high temperature on dairy productivity of Ukrainian Schwyz. Scientific Messenger of LNU of Veterinary Medicine and Biotechnologies, 20(83), 97-101. doi: 10.15421/nvlvet8319

32. Voloshchuk, V. M. \& Khotsenko A. V. (2017). Dynamika temperatury povitria ta vnutrishnikh elementiv konstruktsii korivnyka karkasnoho typu za dii faktoriv zovnishnoho seredovyshcha [Dynamics of air temperature and internal structural elements of the barn frame type on effects of environmental factors]. Visnyk Sumskoho natsionalnoho ahrarnoho universytetu. Seriia : Tvarynnytstvo, 5(2), 37-41. (in Ukrainian)

33. Vysokos, M.P., Milostiviy, R.V., Typina, N.V. \& Kalinichenko, A.O. (2015). Zoogigijenichna ocinka umov utrymannja molochnogo gurtu golshtyns'koi' hudoby za parametramy mikroklimatu monobloku korivnyka v regioni Prydniprov'ja [Hygienic assessing conditions of Holstein dairy cattle in microclimate parameters monoblock cowshed in the region Pridneprovya]. Naukovo-tehnichnyj bjuleten' NDC biobezpeky ta ekologichnogo kontrolju resursiv APK, 3(4), 74-78. (in Ukrainian)

34. Wang, X., Gao, H., Gebremedhin, K. G., Bjerg, B. S., Van Os, J., Tucker, C. B. \& Zhang, G. (2018). A predictive model of equivalent temperature index for dairy cattle (ETIC). Journal of Thermal Biology, 76, 165-170. doi:10.1016/j.jtherbio.2018.07.013

35. Zakharenko, M., Voloshchuk, V. \& Khotsenko, A. (2018). Produktyvnist koriv zarubizhnoi selektsii za bezpryviazno-boksovoho utrymannia ta dii vysokoi temperatury povitria [The productivity of cows of foreign breeding is impairedboxing and exposure to high air temperature]. Naukovyi visnyk NUBiP Ukrainy. Seriia: Tekhnolohiia vyrobnytstva i pererobky produktsii tvarynnytstva, 271, 225-234. (in Ukrainian) 